\title{
Hemşirelerde Örgütsel Sessizliğin Nedenleri: Bir Eğitim ve Araştırma Hastanesi Uygulaması
}

\section{Reasons Of Organizational Silence In Nurses: Implementation Of A Training And Research Hospital}

\author{
Rifat Bilgin ${ }^{a, *}$, Hülya Diğer ${ }^{b}$, Berivan Kaçmaz ${ }^{\mathrm{c}}$ \\ ${ }^{a}$ Doç.Dr. Fırat Üniversitesi, İïBF, Sosyal Hizmet Bölümü, Elazı̆̆ , 23000, Elazığ/Türkiye. \\ ORCID: 0000-0003-1253-3851 \\ b Doktora Öğrencisi, Fırat Üniversitesi, SBE, Sağlık Yönetimi Bölümü, Elazığ, 23000, Elazı̆̆/Türkiye. \\ ORCID: 0000-0002-1737-8195 \\ ${ }^{\text {c }}$ Yüksek Lisans Öğrencisi, Fırat Üniversitesi, SBE, Sağlık Yönetimi Bölümü, 23000, Elazı̆̆/Türkiye. \\ ORCID: 0000-0002-3167-8979
}

\section{MAKALE BİLGİSİ}

\section{Makale Geçmişi:}

Başvuru tarihi: 1 Temmuz 2020

Düzeltme tarihi: 8 Subat 2021

Kabul tarihi: 18 Şubat 2021

\section{Anahtar Kelimeler:}

Sessizlik

Hemşire

Örgütsel Sessizlik
ÖZ

$\mathrm{Bu}$ çalışma, hemşirelerde örgütsel sessizlik problemini incelemeyi amaçlamaktadır. Araştırma örgütsel sessizlik kavramını konu edinmesinin yanı sıra sağlık kurumlarında örgütsel sessizlik konusuna odaklanmaktadır. Araştırmanın evrenini bir eğitim ve araştırma hastanesindeki hemşireler oluşturmaktadır. Araştırmanın örneklemi ise ilgili kurumda görevli olan 306 hemşireden ibarettir. $\mathrm{Bu}$ çalıma için, Fırat Üniversitesi, Sosyal ve Beşeri Bilimler Araştırmaları Etik Kurulu'nda 15/01/2019 tarih ve 306042 sayılı başvuru ile gerekli izin alınmıştır. Elde edilen veriler betimleyici analizlerin yanı sıra, bağımsız örneklem t testi ile Anova testleri yardımıyla analiz edilmiştir. Araştırmanın sonuçlarına göre, hastane yöneticilerinin hemşirelerin örgütsel sessizlik nedenleri konusunda önemli rol oynadığ 1 tespit edilmiştir.

\section{A B S T R A C T}

This study aims to examine the organizational silence problem in nurses. The research focuses on the concept of organizational silence per se as well as the organizational silence in health institutions. The population of the research is nurses working in a training and research hospital. The sample of the research consists of 306 nurses working in the related institution. For this study, the necessary permission was obtained with the application dated 15/01/2019 and numbered 306042 at the Social and Humanities Research Ethics Board of Firat University. The data obtained were analyzed by means of indepedent sample $t$ test and one-way Anova test as well as the descriptive analyzes. According to the results of the research, the hospital managers have been determined to play an important role in the nurses' organizational silence reasons.

\section{Giriş}

Küreselleşme ile birlikte çalışanlar örgütün çeşitli süreçlerinde yer almaya başlamıştır. Ayrıca işgörenlerin sürece dahil edilmesi kurumlar tarafından da amaçlanmaktadır (Gül ve Özcan, 2011). Çünkü işgörenin yüksek katılımının -örgütler açısından rekabetin var olduğu günümüz dünyasında- başarıya katkı sağlayacağ varsayılmaktadır. İşgörenin çalıştığı kurumda çeşitli süreçlerde yer alması sessizlik konusunda rol oynayabilmektedir. Çalışanlarda gözlemlenen örgütsel sessizlik tutumları geçmişte uyum ile bağlılık şeklinde algılanmasına rağmen, günümüzde geri çekilme ile tepki oluşturma şeklinde kabul görmektedir (Bildik, 2009: 4). Çalışanlarda görülen sessizlik durumu, örgütün çalışma atmosferi üzerinde olumsuz etki oluşturabilmektedir. Söz konusu olumsuz sonuçlardan birisi de çalışanların konumları

\footnotetext{
* Sorumlu yazar/Corresponding author

e-posta: rifatbilgin@gmail.com
} 
gereği üstlendikleri sorumluluklardan ziyade gönüllü sergiledikleri performanslarında azalmadır.

Sağlık kurumunun mevcut nitelikleri açısından çevre ile iletişim önemlidir. Söz konusu önem sağlık kurumlarında işgören-müracaatçı ilişkisi ve iletişimi olarak yer almaktadır. Sağl1k hizmetlerinin her süreci, kurum içinde oluşan sosyal ilişkileri örüntüleşmiş bağlantılar üzerinden gerçekleşmektedir. Bu örüntüleşmiş sosyal ilişki biçimleri toplumda var olan değerler ile sosyo-kültürel kodlardan beslenmektedir. Bireylerin ilişki biçimlerindeki davranışları da beslenmeler sonucunda şekillenmektedir. Belirtilen durum göz önünde bulundurulduğunda, sağlık personelinin gerek çalışma arkadaşları ile gerekse de çalıştıkları kurum yöneticileriyle iletişimlerine gereksinim duyulmaktadır.

Dolayısıyla söz konusu çevredeki ilişki biçimleri insan unsurunu ön planda tutma, katılımcı ve demokratik olma gibi başlıklar altında meydana gelmektedir. İletişim başlıkları ile örgütsel sessizlik arasında yakın bir ilişki bulunduğu söylenebilir. Eğer sağlık kurumunda belirtilen yaklaşım ve değerlerin hâkim olduğu bir örgütsel iklim mevcut ise işgörenlerin sessiz kalmamalarının kuruma yönelik memnuniyetlerine fayda sağlayacaktır. Katılımcı bir örgütsel iklimde sağlık personelinin kendine güven çerçevesinde düşüncelerini açık bir şekilde dile getirmesi beklenmektedir. Ancak farklı örgütsel iklimler kapsamında örgütsel sessizlik durumu ile karşı karşıya kalınabilmektedir.

Yukarıda yapılan değerlendirme bağlamında bu çalışmada, hemşirelerde örgütsel sessizliğin nedenleri çeşitli açılardan değerlendirilecektir. Sağlık kurumlarında etkili, verimli ve istenilen şekilde sağlık hizmet sunumunun gerçekleştirilmesi için hemşirelerin sessizlik nedenlerinin bilinmesi çalışmanın amacını oluşturmaktadır. İfade edilen amaç kapsamında yapılan çalışmanın evrenini yarı kamusal mal ve hizmet niteliğinde sağlık hizmetlerini sunan bir eğitim ve araştırma hastanesi oluşturmaktadır. Örneklem ise söz konusu hastanede görevli olan ... hemşireden ibarettir. Çalışmaya katılan hemşirelerin örgütsel sessizlik durumları çeşitli açılardan değerlendirilmiştir.

\section{2. Örgütsel Sessizlik}

Günümüz iş sektöründe rekabet kavramının her geçen gün daha fazla önem kazanması sebebiyle, insan kaynakları ile ilgili bilgi unsurları zaruri bir hal almıştır. Bu bağlamda örgütler kapsamında işgörenler ile uyum kavramının önemi bilinmesine rağmen uygulanmamaktadır. Aksine örgüt tarafından çalışanları sessizliğe yöneltici davranış şekilleri sergilenmektedir. İşgörenlerin geçmişte sessiz kalma durumları uyum, bağlılık ve sayg1 olarak yorumlanabilmiştir. Günümüzde ise sessizlik davranışları doğru bir duruş, düşünce veya eylem olarak kabul edilmemektedir. Dolayısıyla günümüzde işgörenlerin sessizlik durumu, performans açısından tehdit unsuru oluşturabilmektedir. Ayrıca sessizlik, tepki ve geri çekilme gibi davranış şekillerine eşlik etmektedir (Bildik, 2009: 34). Başka bir ifadeyle örgütsel sessizlik, personelin örgütsel problemler hakkındaki değişme, gelişme ile iyi olma durumlarında iş ya da işyeri ile ilgili olan konular (stratejik, teknik vb.) hakkındaki düşüncelerini isteyerek gizleme ve beraberinde sessizleşme olarak ifade edilebilir (Çakıcı, 2007: 149). Aslında örgütsel sessizliğin nedenlerinin bir kısmının ilgili toplumun sosyo-kültürel değerleri ve kodlarından kaynaklandığını da söylemek mümkündür.
Katılımın ve demokratik düşüncenin egemen olmadığı ortamlarda; bireyler tutum ve davranış nedeniyle zor durumda kalabilmektedir. $\mathrm{Bu}$ yaklaşım biçimi ile sosyalleşen veya kültürlenen birey; ailede, sosyal ve iş çevresinde de sukut etmeyi, -bazen gerekli bile olsakendisini ifade etmemeyi tercih etmektedir. Özellikle hemşirelik mesleğinin Türkiye toplumunda çoğunlukla kadın mesleği olarak görülmesi ve sosyo-kültürel ataerkil değerlerde kadının uslu, kocasına veya kaynanasına dil uzatmayan, sessiz, sakin, edepli, -çünkü bazen kadının konuşması edepsizlik olarak değerlendirilebilir- yönetim ve dünyalık işlerde fazla müdahil olmamasının teşvik edildiğini bilinmektedir. Bu unsuların da sağlık kurumlarında özellikle kadın hemşireler arasında örgütsel sessizliğe neden olduğu söylenebilir.

Sağlık çalışanlarında meydana gelen sessizlik davranışı ise, sorumluluğunun üstlenildiği kurum, bölüm ile hizmete yönelik fayda sağlayıcı tecrübe ve bilgilerini çeşitli nedenlerden kaynaklı olarak dile getirmeme veya gizleme olarak tanımlanabilir (Bayın, Yeşilaydın ve Esatoğlu, 2015: 3).

\section{1. Örgütsel Sessizlik Türleri}

Örgütlerde sessizlik türleri üç alt grupta sinıflandırılmaktadır. Bunlar; kabullenici, korunmacı ve korumacı sessizlik olarak ifade edilebilir (Çakıcı, 2010: 31).

\subsubsection{Kabullenici Sessizlik}

Herhangi bir olay, konu veya problem karşısında çalışanların yaşanılanlara razı olup, içerisinde bulunulan durum hakkındaki fikirlerini söylememesi olarak tanımlanmaktadır (Van Dyne, Ang ve Botero, 2003). Söz konusu davranış şekillerini sergileyen bireyler, durumu kabul edip değiştirme ile konuşma konusunda isteksiz ve ilgisizdirler. Kabullenici sessizlik davranışları iş sektöründe "boşuna kürek çekme" düşünce yapısı ile kendini göstermektedir (Çakıc1, 2010: 33). $\mathrm{Bu}$ sessizlik biçimi işgörenin artık çalışılan kurumun düzelmesi, değişmesi konusunda bir tür umutsuzluk, öğrenilmiş çaresizlik veya sinizm durumunu yaşaması olarak da değerlendirilebilir.

\subsubsection{Korunmacı Sessizlik}

Korunmacı sessizlik, işgörenlerin düşüncelerini ifade etmeleri durumunda alacakları tepkiden korkma nedeniyle görüşlerini saklama yoluna giderek sessiz kalması durumu olarak tanımlanabilir. Bireyler söz konusu davranış şekilleri ile kendilerini korumayı amaçlamakta olup, bilinçli olarak sessizlik davranışı sergileme yoluna gitmektedirler (Van Dyne, Ang ve Botero, 2003). Kişilerin belirtilen davranış şeklini sergilemesindeki amaç, sonraki süreçte mevcut durumun sorumluluğunu üstlenmemektir. Ayrıca çalışanların sessiz kalmasındaki diğer bir neden de yapılan hataların ortaya çıkmasını engelleme düşüncesidir (Özgen ve Sürgevil, 2009).

Öte yandan çalışanların meydana gelen olayları sineye çekme durumu da korunmacı sessizlik kapsamında değerlendirilmektedir. Sineye çekme durumu, kişinin açık şekilde düşüncelerini dile getirmesi durumunun sonuçlarından korkması nedeniyle bilerek sessizlik davranışına girmesi durumunda ortaya çıkmaktadır. Sineye çekme durumunda, problemi açık şekilde konuşma ile ikna edilme yoluyla problem çözüme kavuşturulabilir. Bu 
kapsamda personel haksızlı̆̆ın farkında olup, durumu düzeltici davranış şekilleri için uygun zamanı beklemektedir. Kabullenici sessizlik probleminin çözüme kavuşturulabilme sürecinde çalışanların motivasyonlarının artırılması gerekmektedir. Bu bağlamda personele gerekli yardım ile destek sağlanmalıdır (Pinder ve Harlos, 2001). Korunmacı sessizlik daha çok anti-demokratik düşünce, davranış, baskı, eylemlerin hâkim olduğu kurumlarda katılımın az veya hiç olmadığı durumlarda ortaya çıktığı söylenebilir. $\mathrm{Bu}$ tür sessizlik durumunda işgören başına gelebileceklerden korunabilmek için zaman zaman bir tür görünmezlik haline girerek şimşekleri üzerine çekmemek amacıyla da sessizliğe bürünebilmektedir.

\subsubsection{Korumacı Sessizlik}

Korunma amaçlı sessizliğin temelini işbirliği veya fedakârlık oluşturmaktadır. Bu bağlamda mevcut personel, kuruma, çevreye ve diğer personele fayda sağlamak için deneyim, düşünce ile önerilerini gizlemektedir. Kişilerin söz konusu davranış şekillerini sergilemeleri ile işbirliği içerisinde yer almalarının nedeni çevrelerindeki diğer kişileri düşünmelerinden kaynaklanmaktadır. $\mathrm{Bu}$ nedenle korunmacı sessizlik; örgütün faydasına yönelik fedakârlık davranışları şeklinde ortaya çıkmaktadır. Ayrıca kişinin önceden planlama şeklinde meydana gelen davranış şekli olarak da ifade edilebilir. Korumacı sessizlik, korunmacı sessizliğe kıyasla mevcut durum hakkındaki durumları açıkça dile getirmenin sonuçlarından korkma yerine diğer kişilerin iyiliğinin gözetilmesi nedeniyle sessiz kalınmasıdır (Çakıc1, 2010: 34). Bu tür sessizlik bir tür nepotizm ve ideolojik yakınlık, dost-arkadaş ve kurumsal yapının adını ve haysiyetini lekelememe veya adını kötüye çıkarmama amacıyla işgörenin korunmacı davranması şeklindeki bir sessizlik durumudur.

\section{2. Örgütsel Sessizlik Teorileri}

Örgütsel sessizliği anlamaya, işgörenler ve kurumlar için yarattığı avantajlar ile dezavantajlarına yönelik durumları değerlendirmekle ilgili çeşitli teoriler geliştirilmiştir. Bunlar;

\subsubsection{Bekleyiş Teorisi}

Bekleyiş teorisi; liderlik, örgütsel davranış ile ödüllendirme alanları için donanımlı bir kaynaktır. Vroom'a göre bekleyiş teorisi, önceden planlanan eylemin hedeflenen amaç şeklinde sonuçlanmasına dair inancın geçici olması olarak ifade edilebilir. Dolayısıyla söz konusu teori, eylem-sonuç ilişkisini açıklamaktadır. Örneğin, yapılan işte üstün başarı elde etmede çalışmanın başarıya ulaştırmayacağı inancının çalışanda mevcut olması durumunda kişi başarıya ulaşacak gücü kendinde bulamayabilmektedir (Tayfun ve Çatır, 2013: 118-119).

\subsubsection{Fayda-Maliyet Analizi}

Personel tarafindan sessizleşme veya konuşmama durumları meydana gelmeden önce fayda-maliyet analizleri yapılmaktadır. $\mathrm{Bu}$ konuda çalışanların sessiz kalma durumları menfaatlerine göre şekillenmektedir. Bunun sebebi ise, olaylar karşısında örgüt kapsamında ortaya çıkacak tepkilerin işgörene yönelik olumsuz veya olumlu sonuçları olmasından kaynaklanmaktadır. Söz konusu durumda ise işgören fayda-maliyet analizi yaparak ve ilgili eylem durumunu rasyonel bir tutumla ve fayda-maliyet prensibine göre davranışlar sergilemektedir. Fayda-maliyet analizi, örgütlerde açık bir şekilde ortaya çıkmamakta olup, personelin içsel bir davranış şekli olarak meydana gelmektedir. Çalışanların iç dünyasını anlamanın zorluğu sebebiyle sessizlik durumunun meydana gelmesini engellemede zorluğu beraberinde getirmektedir (Kahveci ve Demirtaş, 2010: 11). İşgören doğrudan kendisini ilgilendiren durumlarda bile müdahil olmama yönünde davranmayı tercih edebilmektedir. Bu durumun sebebi daha öncesinde diğer çalışanların davranışlarının gözlemleme yoluyla deneyimleyen çalışanın da bir fayda-maliyet analizi yaptığını söylenebilir.

\subsubsection{Sessizlik Sarmalı Teorisi}

Sessiz kalma durumunun tercih edilme sebeplerinin nasıl temellendirildiği konusunu kendisine konu edinen yaklaşımlardan biri de Noelle-Neumann tarafindan geliştirilen sessizlik sarmalı teorisidir. Teorinin ilk gelişimi kamuoyu çalışmaları kapsamında geliştirilmiştir. $\mathrm{Bu}$ bağlamda kişiler, çoğunluğun fikirlerine dâhil olmamasına rağmen izole olma korkusundan kaynaklı olarak çoğunluğa katılmaktadır. Bu nedenle kişiler, uyum gösterme konusunda yüksek düzeyde farkındalık oluşturabilme adına gerek kişisel gerekse de medya aracılığıyla kamuoyunda mevcut olan egemen görüşü değerlendirmektedirler. Söz konusu değerlendirme sonucuna göre kişi, düşüncesini gizlemekte veya dile getirmektedir. Mevcut teoriye göre kişiler toplumda var olan egemen düşünceyi öğrenme konusunda arayış içerisindedir. Kişinin sahip olduğu düşünce çoğunluğun hâkim olduğu düşünce yapısından farklı ise, düşüncesini dile getirmekten çekinip saklamaktadır. Özetle sessizlik sarmalı, fikrini dile getirmeden önce mevcut fikrin kamu desteğindeki düzeyini değerlendirme durumu olarak ifade edilebilir. Sarmalın devam sürecinde kamu desteğinin zayıf şekilde yer alması, kişinin dışlanma durumunu önceden fark etmesi ile dişlanmadan korkma önemli rol oynamaktadır (Çakıcı, 2007: 153).

Örgüt gelişimi konusunda gereksinim duyulan tartışmalardaki dürüstlük ile açıklık durumu sessizlik sarmalı tarafindan engellenmektedir. Noelle-Neumann'a göre personelin düşüncelerini dürüst bir şekilde açılamayıp gizlemesi durumu, sessizlik sarmalı ile paralel şekilde ortaya çıkan baskı ve izolasyon nedeniyle oluşmaktadır. Kişiler örgütte sahip oldukları fikirlerini açık şekilde dile getirme konusunda düşünce ikliminin ardından konuşma veya sessiz kalma kararına varmaktadırlar (Bildik, 2009).

Sessizlik sarmalı teorisinde var olan varsayımlar şu şekilde ifade edilebilir (Kahveci, 2010: 12):

- Personelin örgüt içerisinde dişlanmaya maruz kalması veya tehdidi,

- Personelin süregelici şekilde dişlanma korkusu ile karşı karşıya kalması,

- Örgüte dışlanma korkusunun beraberinde çalışanın içinde yer aldığ

- Değerlendirme sonucunda çalışanın düşüncesini dile getirme veya sessiz kalma durumunu tercih etmesi.

Aslında sessizlik sarmalı teorisi, belirlenen tek bir doğruya yönelik normatif kurallar ile de ilişkilidir. Çünkü böyle bir çalışma ortamında işgörenler ayırımcılığın karmaşık yapısından dolayı üzerlerinde baskı hissedebilmektedir. Soyutlanmamak ve görünmez kılınmamak için egemen 
düşünce benimsenmekte olup, “mış gibi yaparak veya görünerek” ilgili düşünce veya ideolojinin, kurum kültürünün argümanlarını kullanarak kendisinin görünür hale getirip dışlanmasının veya ötekileştirilmesinin önüne geçilmeye çalışmaktadır.

\subsubsection{Kendini Uyarlama Teorisi}

Kendini uyarlama teorisi ilk olarak Snyder tarafindan 1974 yılında oluşturulmuştur. Snayder'e göre kişiler sosyal olma gereksiniminden hareketle çevre ile topluma yönelik uyum içerisinde bulunmak için çabalamaktadır. Söz konusu çaba kişinin ilişki içerisinde yer aldığı diğer topluluklara da yansımaktadır. Bu hususta birey, toplumsal yaşam içerisinde oluşturduğu imajını takip etmekte ve imajını belirli bir seviyeye göre düzenleyip kontrol altında tutmaya çalışmaktadır (Uçar, 2016: 72).

Bireylerin mevcut şartlarla davranışlarını uyumlaştırması durumu kendini uyarlama teorisi olarak ifade edilebilir. Kendini uyarlama durumları yüksek düzeyde olan kişiler, karşı tarafta iyi bir izlenim oluşturabilmek amacıyla sosyal davranışlarını bilerek değiştirebilme kabiliyetine sahiptirler. Kendini uyarlama düzeyi düşük seviyede bulunan kişiler ise, duygu, düşünce ile fikirlerini karşı tarafa yansıtmaktadırlar. $\mathrm{Bu}$ kişiler kendini uyarlama düzeyi yüksek olan kişilere kıyasla düşüncelerini daha açık bir şekilde dile getirmektedir. Çünkü söz konusu kişiler, davranışları ile kim oldukları arasındaki tutarlılığa önem vermektedir. Ülkemiz kapsamında bireylerin çoğu, davranış seçimlerinde toplum tarafindan beğenilme ile kabul görme unsurlarına göre davranmaktadır (Çakıcı, 2007: 154).

\section{3. Örgütsel Sessizliğe Yol Açan Faktörler}

Örgütsel sessizliğe neden olan faktörler dört başlıkta toplanmaktadır. Bunlar; bireysel nedenler, yönetsel ve örgütsel nedenler, çevresel ve kültürel nedenler ile korku kaynaklı nedenler olarak ifade edilebilir.

\subsubsection{Bireysel Nedenler}

Kişilerin davranış şekilleri, bilgi, beceri ile kişisel özelliklerine bağlı olarak farklılık göstermektedir (Şimşek, 2011).

Sessiz kalma durumu, bireyin kişisel ve demografik niteliklerine, konuya ve bulunan statüye bağlı olarak değişiklik gösterebilmektedir. Örneğin, örgütte var olan herhangi bir konu ile ilgili kişi, arkadaşları ile konuşabilirken, aynı konuyu yöneticisinin karşısında dile getiremeyip sessiz kalmayı tercih edebilmektedir. Sessiz kalma durumunun ortaya çıkmasında demografik unsurlar etki oluşturmaktadır (Özgen ve Sürgevil, 2009: 315-317).

Öte yandan sessiz kalma davranışı üzerinde risk alma eğilimi, özsayg1, benlik saygısı, kontrol odağı vb. kişiye özgü olan bireysel niteliklerde etkili olabilmektedir (Pinder and Harlos, 2001: 354). Bilhassa kişi-grup etkileşimi ile kişinin öz imajı, öz saygısı, kendilik değeri ile kendini algılamasının sonucu şeklinde birey nezdinde ortaya çıkan onaylayıı tepkiler ile kişi düşüncelerini dile getirmekte (Silah, 2005: 159) veya sessiz kalıp kendi içine yönelmektedir (Çakıcı, 2010: 24).

\subsubsection{Yönetsel ve Örgütsel Nedenler}

Örgüt içerisinde sessizlik davranışının yer almasının karşı taraf nezdinde herhangi bir problem oluşturmadığı ve memnuniyet ortamının var olduğu düşüncesini oluştursa da gerçekte problemlerin gizli şekilde yer alması sebebiyle önemli olan bilgilerin gözden kaçmasına, yenilik ile değişim konusunda bir engel oluşturmasına zemin hazırlamaktadır. $\mathrm{Bu}$ sebeple sessizlik kavramı ve beraberindeki davranış şekillerinin, hem kişisel hem de örgütsel performans üzerinde etki oluşturan davranış şekli olarak ele alınması gerekmektedir (Çakıcı, 2010: 37-42).

Sessizlik davranışının ortaya çıkmasında örgütsel faktörler şu şekilde ifade edilebilir (Karacaoğlu ve Cingöz, 2008);

- Çalışılan mekân,

- Hiyerarşik yapının katılığı,

- Kurumda yer alan normlar,

- İnsan ilişkilerinden ziyade iş ilişkilerinin önemli olmas1,

- Merkezi karar verme anlayışı.

Diğer yandan birey-örgüt uyumunun sosyalleşme bakımından incelenmesinde, kişinin başarılı kariyere sahip olması, işinden tatmin olması gibi durumlar bağlılığ artırırken, örgütte başarısız şekilde ortaya çıkan sosyalleşme durumu kişinin örgütten ayrılmasına hatta sessiz kalmasına neden olabilmektedir (Balcı, 2003: 12). Ayrıca örgütsel sosyalizasyon kavramı da kişilerin sessizlik durumları üzerinde etki oluşturan unsurlardan biridir. Bilhassa örgütte yeni yer alan kişi mevcut süreçte algıladığı eksiklik, olumsuzluk veya daha genel şekilde örgüt atmosferinden farklı şekilde yer alan fikir ile düşüncelerini kolaylıkla ifade etmek yerine, sessiz kalmayı seçebilmektedir (Alparslan, 2010: 29).

Örgütsel sessizliğin yönetsel nedenleri şu şekilde ifade edilebilir (Çakıcı, 2010: 29);

- Düşüncelerin açık bir şekilde dile getirilmesinde yönetimin eksik desteği,

- İlişkilerde mesafe,

- Yönetime yönelik güvenin eksik olması,

- Farklı düşüncelere açık olmamak,

- Geri bildirimleri iletmede eksiklik,

- Yönetimde otoriter anlayışın hâkim oluşu,

- Şeffaf yönetim anlayışının bulunmaması,

- Problemlerin dile getirilmesi karşısında olumsuz tepkilerin sergilenmesi.

Premeaux ve Bedeian'nın yapmış oldukları çalışmaya göre, üst yönetim nezdinde şeffaflık düzeyinin artırılması kendini mevcut duruma uyarlamada düşük pozisyonlarda yer alan bireyler üzerinde daha fazla konuşma eğilimi oluşturmaktadır. Öte yandan yönetici desteğinin kişiler üzerinde düşük seviyede olmasını düşünmeleri veya düşündüklerini dile getirdiklerinde herhangi bir olumsuz durumla karşılaşacakları düşüncesi sonucunda kişiler sessiz kalmayı tercih etmektedir (Premeaux ve Bedeian, 2003: 1556).

\subsection{3. Çevresel ve Kültürel Nedenler}

Çalışanlar tarafından sergilenen sessizlik davranışı, yalnızca kişisel, örgütsel veya yönetsel sebeplerden kaynaklanmamaktadır. Dış çevrede yer alan faktörler de sessizlik durumu üzerinde etki oluşturabilmektedir. Sessizlik üzerinde etki oluşturan unsurlardan bir diğeri de "belirsizlik" 
unsurudur. Bilginin ve becerinin açık ve yeterli şekilde yer almadığ 1 , değişmelerin hızlı bir şekilde gerçekleştirildiği, çevresel uyarı ile belirsizliklerin yoğun şekilde var olduğu ortamlarda bireyler, kendilerini tehdit altında hissetme nedeniyle ortama uyum konusunda sıkıntı yaşayabilmektedirler. Bu bağlamda yer alan ortamlarda etkili davranış şekilleri kişilerin becerilerine bağlı şekilde değişiklik göstermektedir. Belirsizlik konusunda toleransları yüksek düzeyde olan kişilerin enformasyon aktarma konusundaki yetenekleri de yüksek düzeyde olmaktadır (Sargut, 1994: 118). Durkheim, bireylerin, yeterli ahlâkî sınırlamayla karşılaşmamaları sebebiyle neyin uygun ve kabul edilebilir bir davranış olup olmadığı konusunda net bir düşüncede olmadıklarını ifade etmektedir. İfade edilen durum anomi olarak isimlendirilmektedir. Anomi aslinda kelime olarak köksüzlük, kuralsızlık veya normsuzluk olarak da tanımlanabilir. Ancak kavram olarak toplumdaki düzenleyici güçler bozulduğunda, düzensizlik, hızlı ekonomik değişmeler ve çöküntü, kolletivitenin bireyler üzerindeki denetiminin azalması veya yok olması gibi hızlı değişim ve dönüşümlerin yaşandığ için de benzer biçimde durumlar gösterdiğini söyleyebiliriz (Ritzer ve Stepnisky, 2014:88-96). Özellikle anomi, toplumsal ve ekonomik bunalım, hizlı toplumsal ve kurumsal normların değişim ve dönüşüm dönemlerinde daha fazla etkinlik kazanmaktadır.

Tüm insanlık nezdinde yer alan evrensel kültür değerleri bulunmasının yanı sıra herhangi bir kültürden diğerine farklılık gösteren ögeler yerel kültürel yapılar da vardır. Kültürel farklılaşma veya kültürel görecelik olarak da adlandırılan mevcut durum, farklı kültürel hayatlarda yaşayan kişilerin kavrama, fikir, tutum ve değerlendirmelerinin de farklılık göstermesine, benzerlik gösteren konu veya koşullarla karşılaştıklarında kişilerin farklı şekilde tepkilerle karşılaşmasına sebep olmaktadır. Kültürler arasında farklılık gösteren tutumlar iletişim, belirsizlikler ile çatışma gibi unsurların üstesinden gelme, güç mesafesi, kişisel-toplumcu davranışlar, denetim noktası vb. konularda meydana gelmektedir (Sargut, 1994: 99).

\subsubsection{Korku Kaynaklı Nedenler}

Çalışanların örgütsel alanlarda sessiz kalmalarında birçok faktörün etkisi bulunmaktadır. Bu faktörler şu şekilde ifade edilebilir (Milliken vd., 2003);

- Örgüt içerisinde çeşitli şekillerde algılanma (şikâyetçi, ispiyoncu, dedikoducu, muhbir, menfaatçi, yardakçı vb.),

- Gerek diğer çalışanlar ile gerekse de yöneticilerle ilişkilerinde negatif etkinin oluşması,

- Başkalarını utandırma, üzme ile zor durum içerisinde bırakma durumu,

- İşi kaybetme ve misilleme ile karşılaşma korkusu,

- Terfi alamama korkusu,

- Başka bir yere gönderilme ve sürgün edilme,

Can ve Alparslan tarafindan 2012 yılında yapılan çalışmaya göre, korku faktörünün sessizlik üzerinde etki oluşturan unsurlardan biri olduğu tespit edilmiştir. Hemşireler üzerinde yürütülen söz konusu çalışma, üst yönetimin tavırlarındaki sertlik, birim değişikliği, işi kaybetme veya daha da zorlaştırma gibi nedenlerle işgörenler arasında korku faktörünün oluşmasında önemli bir yere sahiptir (Can ve Alparslan, 2012).

\section{4. Örgütsel Sessizliğin Sonuçları}

Örgütsel sessizlik davranış ve eyleminin her durumda olumsuz şekilde nitelendirilmesinin doğru olmayabileceği de ifade edilmektedir. Örgütsel sessizliğin katk1 oluşturabileceği durumların da olabileceği Dyne ile Botero tarafindan dile getirilmektedir. Söz konusu durumlar; kişiler arasında oluşan çatışmaların azaltılması, gizli bilgilerin dile getirilmemesi ile yönetsel bilgide bombardımanın azaltılması şeklinde olumlu sonuçlara yol açabilmektedir. Belirtilen çok az sayıdaki olumlu sonuçlarına rağmen örgütsel sessizlik daha ziyade hem çalışan hem de organizasyon kapsamında çoğunlukla zararlı bir olgu olarak değerlendirilmektedir (Tikici vd., 2011: 255). Çalışanların iş yerlerinde düşüncelerini dile getirmeleri durumunda karş1 tarafta negatif etki oluşturmasının çeşitli sonuçları bulunmaktadır. Söz konusu sonuçlar (Durak, 2012: 79) aşağıdaki şekilde olduğu gibi ifade edilmektedir.

- İtibar, güven ile inancı kaybetme,

- Sosyal bağlarda ortaya çıkan zayıflama,

- İşbirliklerinde yoksunluk durumu,

- Diğer çalışanlarla iş yapmada ortaya çıkan zorluk,

- Kariyer firsatları ile terfi olanaklarındaki firsatların azalma olasılı̆̆1,

Örgütsel sessizlik kaynaklı ortaya çıkan problemlerin ilki olarak çalışanlar kapsamında yeni düşüncelerin üretimi ile gelişimlerine kapalı olma durumu yer almaktadır. Örgütün gelişme kaydetme ile örgütün varlığını tam kapasite ile sürdürme sürecinde işgörenlerin yeni düşünceleri önem arz eden bir husustur. Sessizlik kaynaklı ortaya çıkan etkiler, gerek örgüt gerekse de çalışanlar üzerinde negatif etkiler oluşturabilmektedir (Kahveci, 2010: 3). İşgörenler nezdinde sessizlik durumunun oluşması örgüt açısından bir tehdit unsurudur. Söz konusu tehdit, çalışanların işe, kaliteye, işverene ve nihayet örgüte yönelik ilgisiz olmalarıyla sonuçlanabilmektedir. Yöneticilerin işgörenlerin sessizlik durumlarını dikkate almaması, personel nezdinde örgüte ve yapılan işe karşı kayıtsızlık davranışlarını ortaya çıkarmaktadır. Dolayısıyla hem çalışan hem de örgüt zararlı sonuçlar ortaya çıkarabilmektedir (Erigüç vd., 2014). Bir örgüt nitelikleriyle çalışanların sessizliğine temel oluşturuyorsa, çalışanların verimi azalmakta ve kişilerin tercihlerinin önemsiz olduğu düşüncesi oluşmaktadır. Örgütsel sessizlik durumunun üç yıkıcı sonucu olabileceği Milliken ve diğerleri tarafindan belirtilmiştir. Söz konusu sonuçlar (Milliken vd., 2003) ;

- Çalışanların sahip oldukları duygularına dair önemsizlik inancı,

- Çalışanlar tarafindan çevrede oluşan değişiklikleri kontrolde yetersizlik,

- Zihinsel şekilde çalışanların örgüte uyum problemi yaşamaları,

\section{Sağlık Kurumlarında Örgütsel Sessizlik}

Örgütsel sessizlik eylemi ve davranış biçimi örgüt nezdinde birçok tehlikeli sonuçlara sebep olabilmektedir. $\mathrm{Bu}$ bağlamda değerlendirilecek tehlikeli sonuçlardan birisi de örgüt değerleri ile iş kalitesinde oluşan inançsızlık, azalma ve niteliksizleşme durumunun oluşmasıdır (Deniz vd., 2013: 693). Sağlık kurumlarında ortaya çıkan sessizlik durumu diğer kurumlara kıyasla geri dönüşü bulunmayan, vicdani ve ahlaki açıdan büyük yükümlülüklere sebebiyet 
verebilmektedir (Yalçın ve Baykal, 2012). Çünkü sağlık çalışanlarının hizmet verdikleri kişilerin içerisinde bulundukları zihinsel, ruhsal ve fiziksel istırap, örselenme, yaralanma gibi problemler dolayısıyla hemen şimdi iyilik hallerinin sağlanması gerekmektedir. $\mathrm{Bu}$ dezavantajlı kişilere gerekli sağlı hizmetlerinin zamanında sağlanmasından veya işgörenin kayıtsızlığ 1 sebebiyle gerekli teşhis, tedavi ve hizmetin verilmemesi veya geciktirilmesi toplumda birçok problemin -suç, şiddet, ölüm, ailenin parçalanması, maddenin kötü kullanımı, ankisiyete ve depresyon, ekonomik kaynakların kötü kullanılması, yolsuzluk ve iltimas vb- oluşmasını da beraberinde meydana getirebilmektedir. Böylece sağlık kurumları matriks yapısı sebebiyle çeşitli meslek gruplarını bünyesinde barındırmaktadır. Farklı meslek grupları ve diğer farklı pozisyonlarda işgörenleri ile yüksek düzeyde iletişime de gereksinim duyulan bir kurum niteliğine sahiptir. Bu kurum veya kuruşlarda yaşanacak bireysel veya örgütsel sessizlik sorunu ciddi düzeyde toplumsal ve kurumsal problemlere neden olabileceği kolaylıkla söylenebilir. Bu bağlamda sağlık kurumlarında koordinasyonun sürekliliği ile sonuçlarının kolayca telafi edilememesi durumu söz konusu olmaktadır. Ayrıca çalışanların gözlemledikleri durumları, düşüncelerini açık bir şekilde ifade etmemesi durumu, etkili, verimli ve kaliteli bir hizmet sunumuna da engel oluşturabilmektedir. Öte yandan sessizlik durumu örgüt nezdinde var olan örgütsel iklim üzerinde negatif etki oluşturma suretiyle işgörenlerde olumsuz davranışların meydana gelmesine de sebebiyet vermektedir.

Etkili, verimli ve istenen kalitede sağlık hizmeti sunum sürecinde sağlık personelinin iş performansında etki oluşturan her faktörün belirlenmesi önem arz eden bir husustur (Kılınç ve Ulusoy, 2014: 90). Kesintisiz şekilde hizmet sunumu gerçekleştiren hemşireler, çalışan faaliyetleri arasında koordinasyonun sağlanmasında önemli rol oynamaktadırlar (Bayın vd., 2015). Bu bağlamda tedavi, tıbbi hataların azaltımı, kurumsal koordinasyon, hasta takibi konusunda hemşirelik mesleği önemli görevleri ifa etmektedir. Sağlık personeli arasında sayısal çoğunluğu oluşturması ve hasta ile yakından ilişki kuran işgörenlerin başında yer alması gibi sebeplerle bu gurubun örgütsel sessizlik nedenlerinin incelenmesi toplumsal ve kurumsal fayda açısından önem arz etmektedir.

\section{Yöntem ve Uygulama}

$\mathrm{Bu}$ araştırmanın amacı, hemşirelerde örgütsel sessizliğin nedenlerini belirlemektir. Söz konusu amaç kapsamında araştırmanın evrenini, bir eğitim ve araştırma hastanesinde çalışan hemşireler oluşturmaktadır. Araştırmanın evreni 957 hemşireden ibarettir. Araştırmanın örneklem sayısı, \%95 güven düzeyinde ilgili formül ${ }^{1}$ kullanılarak hesaplanmış olup, 278 kişi olarak belirlenmiştir. Bu çalıma için, Fırat Üniversitesi, Sosyal ve Beşeri Bilimler Araştırmaları Etik Kurulu'nda 15/01/2019 tarih ve 306042 sayılı başvuru ile gerekli izin alınmıştır.

Ayrıca örgütsel sessizlik ölçeği, Çakıcı tarafından 2008 y1lında geliştirilen ve üniversiteler kapsamında 327 akademik, 181 idari personelin katılımıyla gerçekleştirilen KMO değerinin 0,94 ve Alpha katsayısının 0,94 olması ile
“Örgütsel Sessizlik Nedenleri”; Kahveci ve Demirtaş tarafından 2013 yılında geliştirilen ve 20 ilköğretim okulunda görevli 426 öğretmenin katılımıyla geliştirilen KMO değerinin \%87 ve Alpha katsayısının 0.89 olması ile "Örgütsel Sessizlik Ölçeğinden" faydalanılarak geliştirilmiştir (Çakıc1, 2008: 117; Kahveci ve Demirtaş, 2013: 167).

Geliştirilen ölçeğin pilot uygulaması 100 hemşirenin katılımıyla yapılmıştır. Pilot uygulama sonrası geçerlilik ve güvenilirlik analizleri yapılmıştır.

Açımlayıcı faktör analizi sonuçları Tablo 1'de yer almaktadir.

Tablo 1. Faktör Analizi Sonuçları

\begin{tabular}{|c|c|c|c|c|c|}
\hline & 清 & 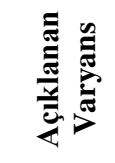 & $\underset{1}{0}$ & : & 2 \\
\hline Yönetici & & $\mathbf{3 8 , 5 5 7}$ & 0,879 & 0,896 & 0,000 \\
\hline 9 & 0,907 & & & & \\
\hline 1 & 0,764 & & & & \\
\hline 6 & 0,738 & & & & \\
\hline 10 & 0,649 & & & & \\
\hline 8 & 0,597 & & & & \\
\hline 2 & 0,586 & & & & \\
\hline 7 & 0,585 & & & & \\
\hline 5 & 0,494 & & & & \\
\hline $\begin{array}{l}\text { Sessizliğin } \\
\text { Kaynağı }\end{array}$ & & 12,895 & 0,758 & 0,889 & 0,000 \\
\hline 18 & 0,894 & & & & \\
\hline 17 & 0,732 & & & & \\
\hline 20 & 0,676 & & & & \\
\hline 22 & 0,633 & & & & \\
\hline 21 & 0,586 & & & & \\
\hline $\begin{array}{c}\text { İş İle İlgili } \\
\text { Korku }\end{array}$ & & 5,081 & 0,756 & 0,794 & 0,000 \\
\hline 13 & 0,911 & & & & \\
\hline 15 & 0,800 & & & & \\
\hline 14 & 0,513 & & & & \\
\hline
\end{tabular}

1 Örneklem büyüklüğünü hesaplama (Sample Size Calculator) sistemi kullanılarak örneklem büyüklüğü bulunmuştur (https://www.surveysystem.com/sscalc.htm, Erişim tarihi:19.05.2020). 


\begin{tabular}{|c|c|c|c|c|c|}
\hline 16 & 0,483 & & & & \\
\hline $\begin{array}{c}\text { İlişkileri } \\
\text { Zedeleme } \\
\text { Korkusu }\end{array}$ & & 3,400 & 0,796 & $\mathbf{0 , 8 2 4}$ & $\mathbf{0 , 0 0 0}$ \\
\hline 4 & 0,694 & & & & \\
\hline 11 & 0,591 & & & & \\
\hline 19 & 0,572 & & & & \\
\hline 3 & 0,452 & & & & \\
\hline 12 & 0,316 & & & & \\
\hline $\begin{array}{c}\text { Açıklanan } \\
\text { Varyans } \\
(\%)\end{array}$ & & & 66,807 & & \\
\hline КМO & & & ,872 & & \\
\hline $\begin{array}{c}\text { Cronbach } \\
\text { Alpha } \\
\end{array}$ & & & ,926 & & \\
\hline
\end{tabular}

Yapılan açımlayıcı faktör analizi sonuçlarına göre ölçek dört faktörden oluşmaktadır. Ölçekte yer alan ifadelerin faktör yükleri 0,316 ile 0,911 arasında değişmektedir. Bununla birlikte ölçeğin açıkladığı toplam varyans oranı $\% 66,80$ 'dir. Çok boyutlu ölçeklerde faktörlerin toplam varyansın minimum \%50'sini açılaması yeterli olarak kabul görmektedir. Ayrıca KMO değerinin $0,872(\mathrm{p}=0,000)$ olması, örneklemin faktör analizi açısından yeterli olduğunu ifade etmektedir. (Gürbüz ve Şahin, 2016: 319).

Ölçeği oluşturan faktörlerin; yönetici, sessizliğin kaynağı, iş ile ilgili korku ve ilişkileri zedeleme korkusu şeklinde isimlendirilmeleri uygun görülmüştür. Faktör isimlendirilmeleri uzman görüşü alınarak yapılmıştır. Bu bağlamda faktör isimleri ölçeğin geliştirilmesinde kullanılan ölçek faktörleri ile benzerlik göstermektedir.

Faktör yüklerine bağlı olarak faktörler altında yer alan soru maddeleri incelenmiştir. Buna göre yönetici faktörü altında sekiz soru $(9,1,6,10,8,2,7,5)$; sessizliğin kaynağı faktörü altında beş soru $(18,17,20,22,21)$; iş ile ilgili korku faktörü altında dört soru $(13,15,14,16)$; ilişkileri zedeleme korkusu faktörü altında beş soru $(4,11,19,3,12)$ yer almaktadır.

325 hemşireden veriler toplanmış olup, 19 anket eksik ya da yanlış olması sebebiyle analiz sürecine dâhil edilmemiştir. 306 kişiden elde edilen veriler, SPSS 22.0 for Windows paket programı ile araştırma amaçları doğrultusunda çeşitli istatistiksel analizlere tabi tutulmuştur. Elde edilen verilere ilk olarak betimleyici analizler uygulanmıştır. Betimleyici analizlerden sonra verilere normallik testi uygulanmıştır. Normallik testi sonuçları Tablo 2'de yer almaktadır.

Tablo 2. Normallik Testi Sonuçları

\begin{tabular}{cc}
\hline Çarpıklık & Basıklık \\
\hline$-0,615$ & 0,492 \\
\hline
\end{tabular}

Analiz aşamasına geçilmeden verilerin normallik durumları çarpıklık basıklık katsayılarına göre incelenmiştir. Örgütsel sessizlik ölçeğine ilişkin değeri $-0,615$ ve basıklık değeri 0,492 olarak elde edilmiştir. Bu değerler -1.96 ile +1.96 aralığında (Tabachnick ve Fidell, 2007) yer aldığından dolayı örgütsel sessizlik ölçeği ile toplanan verilerin normallik varsayımı adına normal dağılım sergilediğine işaret etmektedir.

Katılımcıların örgütsel sessizlik durumlarını demografik değiş̧enlere göre karşılaştırmak amacıyla Bağımsız Örneklem t testi ve ANOVA analizi yapılmıştır. İki bağımsız grup ortalamalarını karşılaştırmak amacıyla Bağımsız Örneklem $\mathrm{t}$ testi, üç veya daha fazla sayıda grubun ortalamaları arasındaki farklılı̆g karşıllaştırmak için ise, ANOVA analizi uygulanmıştır.

Araştırmanın hipotezleri şu şekilde ifade edilebilir;

H1: Örgütsel sessizliğin nedenleri cinsiyete göre farklılaşmaktadır.

H2: Örgütsel sessizliğin nedenleri yaşa göre farklılaşmaktadır.

H3: Örgütsel sessizliğin nedenleri eğitime göre farklılaşmaktadır.

H4: Örgütsel sessizliğin nedenleri çalışma yılına göre farklılaşmaktadır.

H5: Örgütsel sessizliğin nedenleri görev yerine göre farklılaşmaktadır.

\subsection{Araştırmanın Bulguları}

306 hemşireden elde edilen verilere ilişkin demografik bilgiler Tablo 3'te yer almakta olup, aşağıda sunulmuştur.

Tablo 3. Katılımcıların Demografik Özelliklerine Göre Dağılımları

\begin{tabular}{|c|c|c|c|c|c|}
\hline Cinsiyet & $\mathbf{F}$ & $\%$ & Görev Yeri & $\mathbf{F}$ & $\%$ \\
\hline $\begin{array}{l}\text { Kadın } \\
\text { Erkek }\end{array}$ & $\begin{array}{l}172 \\
134\end{array}$ & $\begin{array}{l}56,2 \\
43,8\end{array}$ & $\begin{array}{c}\text { Acil Birim } \\
\text { Cerrahi } \\
\text { Birimler } \\
\text { Dahili } \\
\text { Birimler } \\
\text { Yoğun } \\
\text { Bakım } \\
\text { Diğer }\end{array}$ & $\begin{array}{l}32 \\
90 \\
60 \\
80 \\
44\end{array}$ & $\begin{array}{l}10,5 \\
29,4 \\
19,6 \\
26,1 \\
14,4\end{array}$ \\
\hline Yaş & $\mathbf{F}$ & $\%$ & Eğitim & $\mathbf{F}$ & $\%$ \\
\hline $\begin{array}{c}16-25 \\
26-35 \\
36-45 \\
46 \text { ve üzeri }\end{array}$ & $\begin{array}{c}58 \\
203 \\
44 \\
1\end{array}$ & $\begin{array}{c}19,0 \\
66,3 \\
14,4 \\
, 3\end{array}$ & $\begin{array}{l}\text { İlköğretim } \\
\text { Lise } \\
\text { Ön Lisans } \\
\text { Lisans } \\
\text { Lisansüstü }\end{array}$ & $\begin{array}{c}2 \\
28 \\
43 \\
219 \\
14\end{array}$ & $\begin{array}{c}, 7 \\
9,2 \\
14,1 \\
71,6 \\
4,6\end{array}$ \\
\hline
\end{tabular}

\begin{tabular}{llllll}
\hline Çalışma Yılı & F & $\%$ & Toplam & F & $\%$ \\
\hline
\end{tabular}




$\begin{array}{cccccc}0-5 & 130 & 42,5 & & & \\ 6-10 & 126 & 41,2 & \text { Toplam } & 306 & 100 \\ 11-20 & 41 & 13,4 & & & \\ 21+ & 9 & 2,9 & & & \end{array}$

Hemşirelerden elde edilen demografik bilgiler ile ilgili dikkat çekici özellikler şu şekilde özetlenebilir: Çalışmaya katılan 306 hemşirenin \%56,2'si kadın \%43,8'i erkek olup, \%66,3'ü 26-35 yaş arasındadır. Katılımcıların \%42,5'inin 05 yıl arasında çalıştıkları, \%29,4'ünün cerrahi birimlerde çalışması ve \%71,6'sının lisans mezunu olması yapılan analiz sonucunda elde edilen diğer demografik bilgiler arasindadir.
Araştırmada elde edilen verilerin aritmetik ortalamaları alınmıştır. Düzey durumları ortalamalara göre belirlenmiş olup, düzey sıralaması şu şekilde değerlendirilmiştir: 1,25< ortalama $<=2,50$ : düşük; $2,50<$ ortalama $<=3,75$ : vasat; $3,75<$ ortalama $<=5,00$ : yüksek.

Araştırmanın düzey aralıkları kullanılan ölçek türünün özelliğine göre belirlenmiştir. Ölçek 5'li likert tipi olup, 4 aralığa sahiptir. Ölçek türünün aralık sayısına bölünmesi yolu ile düzey tespiti yapılmıştır. Buna göre 5/4=1.25 şeklinde düşük düzeyin minimum değeri 1.25 olarak belirlenmiştir. Daha sonra ise 1.25 değerin eklenmesi yoluyla diğer düzey aralıkları tespit edilmiştir. Dolayısıyla $1,25<$ ortalama $<=2,50$ : düşük; $2,50<$ ortalama $<=3,75$ : vasat; $3,75<$ ortalama <= 5,00: yüksek düzey olarak isimlendirilmiştir.

Tablo 4. Ölçekte Yer Alan İfadelerin Frekans, Yüzde, Ortalama ve Standart Sapmaları

\section{Kesinlikle Katılmıyorum}

2. Katılmıyorum

3. Kararsızım

4. Katılıyorum

N: Kişi

Sayısı

5. Kesinlikle Katılıyorum

\begin{tabular}{|c|c|c|c|c|c|c|c|c|}
\hline \multirow{2}{*}{$\begin{array}{l}\text { 1.Hastane yöneticilerinin "en iyi ben bilirim" tavrı hemşireler } \\
\text { üzerinde olumsuz bir etki yaratır. }\end{array}$} & $\mathbf{N}$ & 7 & 12 & 35 & 105 & 147 & ,95 & 4,21 \\
\hline & $\%$ & 2,3 & 3,9 & 11,4 & 34,3 & 48,0 & & \\
\hline \multirow{2}{*}{$\begin{array}{l}\text { 2.Hemşirelerin görüşlerini dile getirememesi, yöneticilerin } \\
\text { otoriter davranışlarından kaynaklanmaktadır. }\end{array}$} & $\mathbf{N}$ & 10 & 16 & 51 & 131 & 98 & ,99 & 3,95 \\
\hline & $\%$ & 3,3 & 5,2 & 16,7 & 42,8 & 32,0 & & \\
\hline \multirow{2}{*}{$\begin{array}{l}\text { 3.Hemşireler düşüncelerini açıkça dile getirmelerinin } \\
\text { faydasız olduğuna inandıkları için susmayı tercih ederler. }\end{array}$} & $\mathbf{N}$ & 22 & 26 & 54 & 94 & 110 & 1,21 & 3,79 \\
\hline & $\%$ & 7,2 & 8,5 & 17,6 & 30,7 & 35,9 & & \\
\hline \multirow{2}{*}{$\begin{array}{l}\text { 4.Daha önce açıkça konuşanların yöneticiler tarafindan } \\
\text { haksızlığa maruz kalarak emsal oluşturması nedeniyle } \\
\text { hemşireler susarlar. }\end{array}$} & $\mathbf{N}$ & 7 & 23 & 52 & 101 & 123 & 1,04 & 4,01 \\
\hline & $\%$ & 2,3 & 7,5 & 17,0 & 33,0 & 40,2 & & \\
\hline \multirow{2}{*}{$\begin{array}{l}\text { 5.Hemşireler yöneticilerin eksikliklerini bilmelerine rağmen } \\
\text { bu durumu dile getirmez. }\end{array}$} & $\mathbf{N}$ & 6 & 37 & 61 & 108 & 94 & 1,06 & 3,80 \\
\hline & $\%$ & 2,0 & 12,1 & 19,9 & 35,3 & 30,7 & & \\
\hline \multirow{2}{*}{$\begin{array}{l}\text { 6.Hastane yöneticilerinin adil davranmaması, hemşirelerin } \\
\text { görüşlerini açıklamalarına engel olmaktadır. }\end{array}$} & $\mathbf{N}$ & 5 & 19 & 47 & 111 & 124 & ,97 & 4,07 \\
\hline & $\%$ & 1,6 & 6,2 & 15,4 & 36,3 & 40,5 & & \\
\hline \multirow{2}{*}{$\begin{array}{l}\text { 7.Hemşireler görüşlerini açıkça ifade ettiklerinde } \\
\text { yöneticilerden ve meslektaşlarından olumsuz tepki alırlar. }\end{array}$} & $\mathbf{N}$ & 12 & 26 & 55 & 125 & 88 & 1,06 & 3,82 \\
\hline & $\%$ & 3,9 & 8,5 & 18,0 & 40,8 & 28,8 & & \\
\hline
\end{tabular}

\begin{tabular}{|c|c|c|c|c|c|c|c|c|}
\hline \multirow{2}{*}{$\begin{array}{l}\text { 8.Hastane yöneticilerinin performanslarının düşük olması, } \\
\text { hemşirelerin sorunları dile getirmesini engeller. }\end{array}$} & $\mathbf{N}$ & 11 & 26 & 48 & 131 & 90 & 1,04 & 3,85 \\
\hline & $\%$ & 3,6 & 8,5 & 15,7 & 42,8 & 29,4 & & \\
\hline \multirow{2}{*}{$\begin{array}{l}\text { 9.Hemşireler düşüncelerini açıç̧a dile getirmemesinin } \\
\text { sebeplerinden biriside yöneticilerin "sözde" ilgileniyor } \\
\text { olmasıdır. }\end{array}$} & $\mathbf{N}$ & 9 & 17 & 49 & 118 & 113 & 1,00 & 4,00 \\
\hline & $\%$ & 2,9 & 5,6 & 16,0 & 38,6 & 36,9 & & \\
\hline
\end{tabular}

\begin{tabular}{|c|c|c|c|c|c|c|c|c|}
\hline \multirow{2}{*}{$\begin{array}{l}\text { 10.Hiyerarşik yapının katılığı nedeniyle hemşireler sorunları } \\
\text { dile getirmekten kaçınırlar. }\end{array}$} & $\mathbf{N}$ & 5 & 35 & 55 & 99 & 112 & 1,07 & 3,90 \\
\hline & $\%$ & 1,6 & 11,4 & 18,0 & 32,4 & 36,6 & & \\
\hline \multirow{2}{*}{$\begin{array}{l}\text { 11.Hemşireler sorun bildirenlerin hoş karşılanmayacağ } 1 \\
\text { düşüncesi ile susmayı tercih ederler. }\end{array}$} & $\mathbf{N}$ & 19 & 41 & 45 & 131 & 70 & 1,15 & 3,62 \\
\hline & $\%$ & 6,2 & 13,4 & 14,7 & 42,8 & 22,9 & & \\
\hline
\end{tabular}




$\begin{array}{lllllllllll}\text { 12.Hemşireler sorun bildirdiğinde } & \text { görev } & \text { yeri değişme } & \mathbf{N} & 16 & 40 & 27 & 128 & 95 & 1,16 & 3,80 \\ \text { korkusu nedeni ile sorunları dile getirmezler. } & & & & & & & & \end{array}$

\begin{tabular}{|c|c|c|c|c|c|c|c|c|}
\hline \multirow{2}{*}{$\begin{array}{l}\text { 13.Hemşireler yeni fikir ve öneriler iş yükünü artırabilir } \\
\text { düşüncesinden dolayı susarlar. }\end{array}$} & $\mathbf{N}$ & 35 & 51 & 70 & 84 & 66 & 1,29 & 3,31 \\
\hline & $\%$ & 11,4 & 16,7 & 22,9 & 27,5 & 21,6 & & \\
\hline
\end{tabular}

\begin{tabular}{|c|c|c|c|c|c|c|c|c|}
\hline \multirow{2}{*}{$\begin{array}{l}\text { 14.Hemşireler kurumdaki geleceklerine dair kaygıları } \\
\text { nedeniyle kendilerine ait yeni fikirleri söylemezler. }\end{array}$} & $\mathbf{N}$ & 17 & 31 & 66 & 118 & 74 & 1,11 & 3,65 \\
\hline & $\%$ & 5,6 & 10,1 & 21,6 & 38,6 & 24,2 & & \\
\hline
\end{tabular}

\begin{tabular}{|c|c|c|c|c|c|c|c|c|}
\hline \multirow{2}{*}{$\begin{array}{l}\text { 15.Hemşireler çalışma arkadaşlarının katılmadığı, işle ilgili } \\
\text { konular hakkındaki fikirlerini ifade etmezler. }\end{array}$} & $\mathbf{N}$ & 29 & 53 & 69 & 90 & 65 & 1,25 & 3,35 \\
\hline & $\%$ & 9,5 & 17,3 & 22,5 & 29,4 & 21,2 & & \\
\hline \multirow{2}{*}{$\begin{array}{l}\text { 16.Hemşirelerin bilgisizlik ve deneyimsizlik korkusu } \\
\text { duygularını ifade etmelerine engel olur. }\end{array}$} & $\mathbf{N}$ & 50 & 52 & 51 & 107 & 46 & 1,32 & 3,15 \\
\hline & $\%$ & 16,3 & 17,0 & 16,7 & 35,0 & 15,0 & & \\
\hline \multirow{2}{*}{$\begin{array}{l}\text { 17.Hemşireler güç durumda konuşmaktan çok susmayı tercih } \\
\text { ederler. }\end{array}$} & $\mathbf{N}$ & 30 & 33 & 59 & 134 & 50 & 1,17 & 3,46 \\
\hline & $\%$ & 9,8 & 10,8 & 19,3 & 43,8 & 16,3 & & \\
\hline \multirow{2}{*}{$\begin{array}{l}\text { 18. Hemşireler alt kademede olduklarından dolayı bazı } \\
\text { durumlarda susmayı tercih ederler. }\end{array}$} & $\mathbf{N}$ & 38 & 36 & 67 & 88 & 77 & 1,31 & 3,42 \\
\hline & $\%$ & 12,4 & 11,8 & 21,9 & 28,8 & 25,2 & & \\
\hline
\end{tabular}

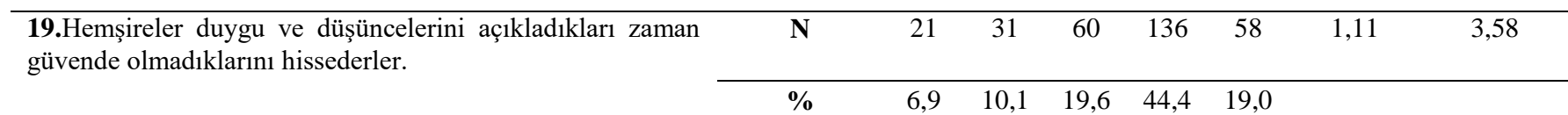

\begin{tabular}{llcccccccc}
\hline $\begin{array}{l}\text { 20.Hemşireler dişlanacakları endişesi ile sorunları dile } \\
\text { getirmezler. }\end{array}$ & $\mathbf{N}$ & 32 & 39 & 65 & 123 & 47 & 1,19 \\
\cline { 3 - 9 } & & & & & & & \\
\end{tabular}

Adaletin hâkim olduğu bir toplum ve kurumu anlayabilmek için sormamız gerekenler; hak ettiğimiz gelirin, sorumluluk ve hakların, güçlerin ve firsatların, pozisyon ve rütbeler gibi değerlerin doğru bir şekilde dağıtılmasıdır. Adil örgüt her bireye hak ettiğini verir (Sandel, 2014: 41). İşin adil olabilmesi için o işi yapan işgörenin doğasıyla uyumlu olması gerekir. Bazı işler bu sınavı geçemez. Tehlikeli, tekrara dayanan ve monoton işler; zarar verici ve sıkıcı olduklarından dolayı insanoğluna uygun değildir. $\mathrm{Bu}$ durumda adalet, işin insan doğasına uygun organize edilmesini gerektirir. Aksi takdirde bu işler köleliğe benzer nitelikler içerdiğinden adaletsiz olacaktır (Sandel, 2014: 269). Dolayısıyla A'nın nesnel olarak B'yi sömürdüğü veya sorumlu kişi olarak ilgili kişinin $-\mathrm{ki}$ bu bir işgören de olabilir- özgüvenini pekiştirmesini engellediği herhangi bir durum baskı şeklinde tanımlanabilir. Böyle bir durum, sahte yüceliklerle şirinlikler gösterilse de, kendiliğinden şiddet yaratır. Çünkü insanın yetkin insan olma yönündeki ontolojik ve tarihi yetisini engelleyen bir baskı ilişkisiyle şiddet zaten başlamıştır (Freire, 2018: 39). Öyleyse bir işin önce insan doğasına uygun düzenlenmesi ve insanın kendilik değeri ve özsaygısını zedelemeyip baskı oluşturmaması gerektirmektedir. Dolayısıyla yukarıdaki ölçek maddeleri bu açıklamalar çerçevesinde işin adil ve insan doğasına uygun olması, ilişki biçimlerinin ve uygulamaların şiddet, baskı içeren bir nitelik taşımaktan ziyade demokratik ve katılımın yüksek olduğu bir bakış açısı benimsenerek değerlendirilmiştir.

Tablo 4'te çalışmaya katılan katılımcıların kendilerine yöneltilen ifadelendirmelere verdikleri yanttların frekans dağılımlarına yer verilmektedir. Bu ifadeler aracılığıyla hemşirelerin kurumsal alanda sergiledikleri örgütsel sessizlik nedenleri yorumlanmasına, değerlendirilmesine ve işgörenler açısından var olan eksikliklerin gözden geçirilmemesine de imkân tanımaktadır. 
Sağlık kurumlarında farklı pozisyonlarda (işgören, yönetici) görev alan personelin hem farklı pozisyonlarda yer alanlar hem de aynı pozisyonlarda görev alanlar birbirlerini verimli, kaliteli iş yapma veya yapmama, aksatma, kayıtsız davranama, geri çekilme gibi olumlu ve olumsuz yönden etkileyebilmektedirler. Söz konusu etki mevcut duruma göre farklılık göstermesine ek olarak kişisel özelliklerden de kaynaklanmaktadır. Bu bağlamda katılımcılara yöneltilen "Hastane yöneticilerinin "en iyi ben bilirim" tavr hemşireler üzerinde olumsuz bir etki yaratır." sorusuna \%82,3'ü olumlu yanıt verirken, \%11,4'ü kararsız olduklarını belirtmişlerdir. Ayrıca soruya verilen yanıtların ortalaması 4,21 olarak tespit edilmiştir. Dolayısıyla hastane yöneticilerinin davranışlarından kaynaklı olarak örgütsel sessizlik durumunun görülme sıklığı yüksek düzeydedir. Hatta hemşirelerin büyük bir kısmının bu olumsuz tutuma maruz kaldıkları veya bu ilgi duruma ilişkin olumsuz bir tutum benimsedikleri söylenebilir.

Yöneticilerin davranışlarını şekillendiren unsurlar kişisel özelliklerinin yanı sıra hâkim olan yönetim düşüncesinden de kaynaklanmaktadır. Bu konuda merkezi yönetim ve denetim alanın dar olması gibi unsurların var olduğu kurumlarda otoriter yap1 ortaya çıkmaktadır. Bu hususta katılımcılara yöneltilen "Hemşirelerin görüşlerini dile getirememesi, yöneticilerin otoriter davranışlarından kaynaklanmaktadır." sorusuna katılımciların \%54,8'i olumlu yanıt verirken \%16,7'si kararsız olduklarını ifade etmiştir. Öte yandan soruya verilen yanıtların ortalaması 3,95 olarak belirlenmiştir. Dolayısıyla otoriter yapının hâkim olduğu kurumlarda mevcut durum sebebiyle ortaya çıkan örgütsel sessizlik durumu görülmesinin yüksek düzeyde olduğu öngörülmektedir.

İşgörenlerin yaptıkları iş ve örgüt hakkındaki istek, öneri ile şikâyetleri örgütsel gelişim ve değişim açısından önem arz etmektedir. Söz konusu hususa verilen önem işgörenlere, sunulan hizmete ve dolayısıyla örgüte olumlu katkılar sağlamaktadır. $\mathrm{Bu}$ konuda katılımcılara yöneltilen "Hemşireler düşüncelerini açıkça dile getirmelerinin faydasız olduğuna inandıkları için susmayı tercih ederler." sorusuna katılımciların \%66,6's1 olumlu yanıt verirken, \%17,6'sı kararsız olduklarını belirtmiştir. Bununla birlikte soruya verilen yanıtların ortalaması 3,79 olarak tespit edilmiştir. Dolayısıyla hemşirelerin düşüncelerini açıkça ifade etmelerinin kurumu yöneticilerinin tutum, tavır, davranış ve iş yapma biçimlerini etkileyemeyeceğini veya değiştiremeyeceğine ilişkin düşünce, deneyimlere sahip olduklarından fayda oluşturamayacağına dair inancın kaybedilmesi nedeniyle örgütsel sessizlik durumunun gözlemlenmesi arasında yüksek düzeyde bir ilişki öngörülmektedir.

Örgütsel sessizlik sebeplerinden biri de şüphesiz hemşirelerin kendi düşünce ve iş yapma biçimlerini ifade etmeleri sonrasında kendilerinin veya arkadaşlarının karşılaştıkları veya karşılaşılabilecek yönetici yaklaşımlarına ilişkin oluşan korkularıdır. Bu bağlamda katılımcılara yöneltilen "Daha önce açıkça konuşanların yöneticiler tarafindan haksızliğa maruz kalarak emsal oluşturması nedeniyle hemşireler susarlar." sorusuna katılımcıların \%73,2'si olumlu yanıt verirken, 17'si kararsız olduklarını belirtmiştir. Ayrıca soruya verilen yanıtların ortalaması 4,01 olarak belirlenmiştir. Dolayısıyla yöneticiler haksız bir yaklaşım veya ilişki biçimi geliştirseler bile karşı çıkmadıkları ve çoğunlukla eylemi görmezden gelip veya kendilerini görünmez kılma adına örgütsel sessizlik durumunu seçtikleri söylenebilir.

Örgütlerde genel manada ortaya çıkan örgütsel sessizlik durumu, negatif sonuçlara maruz kalabilme düşüncesi ile ortaya çıkmaktadır. Söz konusu negatif durumlar nedeniyle işgörenler birçok düşünce ve iş yapabilme biçimlerini dile getir(e)memektedirler. Bu hususta katılımcılara yöneltilen "Hemşireler yöneticilerin eksikliklerini bilmelerine rağmen bu durumu dile getirmez." sorusuna katılımciların \%66's1 olumlu yanıt verirken, \%19,9'sı kararsız olduklarını ifade etmiştir. Ayrıca soruya verilen yanıtların ortalaması 3,80 olarak tespit edilmiştir. Dolayısıyla çeşitli sebepler ile ortaya çıkan işgörenlerin, yöneticilerine veya kendilerinden daha üst pozisyonda bulunanlara düşüncelerini dile getiremedikleri sonucu ortaya çıkmaktadır.

Örgütlerde adalet kavramına riayet ve akabinde meydana gelen durumlar, örgütsel sessizlik sürecinde önemli rol oynamaktadır. Bu konuda katılımc1lara yöneltilen "Hastane yöneticilerinin adil davranmamasl, hemşirelerin görüşlerini açıklamalarına engel olmaktadır." sorusuna katılımcıların \%76,8'si olumlu yanıt verirken, \%15,4'ü kararsız olduklarını ifade etmiştir. Ayrıca soruya verilen yanıtların ortalaması 4,07 olarak belirlenmiştir. Dolayısıyla adalet kavramının örgütsel sessizlik açısından yüksek düzeyde bir role sahip olduğu söylenebilmektedir.

Örgütlerde var olan durumun çoğunluk tarafindan kabul durumu, zıt görüşe sahip olanlar açısından negatif durum ortaya çıkarmaktadır. Bu konuda katılımcılara yöneltilen "Hemşireler görüşlerini açıkça ifade ettiklerinde yöneticilerden ve meslektaşlarından olumsuz tepki alırlar." sorusuna katılımcıların \%69,6's1 olumlu yanıt verirken, \%18'i kararsız olduklarını belirtmiştir. Öte yandan soruya verilen yanıtların ortalaması 3,82 olarak belirlenmiştir. Dolayısıyla hemşirelerin açıkça bir görüş ifade ettikleri zaman çoğunlukla yöneticileri ve meslektaşları tarafindan bunun kabul görmemesi veya karşı taraftan gelecek olumsuz bir davranış ve eylemle karşılaşma olasılığı nedeniyle kendilerini ifade etmedikleri görülmektedir. Bu sonuçlardan hareketle hemşerilerin düşüncelerini açıkça ifade etme yoluna gitmeden örgütsel sessizlik durumu içerisinde yer aldıkları söylenebilir.

Hastane yöneticilerinin liderlik vasıfları ve nitelikleri örgütün işleyiş süreci ve performansı üzerinde etki oluşturmaktadır. $\mathrm{Bu}$ bağlamda katılımcılara yöneltilen "Hastane yöneticilerinin performanslarının düşük olması, hemşirelerin sorunlarl dile getirmesini engeller." sorusuna katılımcıların \%72,2'si olumlu yanıt verirken, \%15,7'si kararsız olduklarını ifade etmiştir. Ayrıca soruya verilen yanıtların ortalaması 3,85 olarak belirlenmiştir. Dolayısıyla ilgili işgörenlerin çoğunluğuna göre yöneticilerin düşük performanslara sahip oldukları ve bu durumu yöneticilerine ifade edemediklerini veya etme cesaretinde bulunmadıklarını ifade etmektedirler. Nihayetinde hemşirelerin örgütsel sessizlik durumları ile hastane yöneticilerinin nitelikleri arasında yakın ilişki olduğu öngörülmektedir.

Örgüt düzeni ve uygulama süreçlerinde yer alan hastane yöneticilerinin önem arz eden hususlarından bir diğeri de işgörenleri ile ilgilenme düzeyleridir. $\mathrm{Bu}$ konuda 
katılımcılara yöneltilen "Hemşireler düşüncelerini açıça dile getirmemesinin sebeplerinden biriside yöneticilerin "sözde" ilgileniyor olmastdır." sorusuna katılımcıların \%72,2'si olumlu yanıt verirken, \%15'si kararsız olduklarını belirtmiştir. Öte yandan soruya verilen yanıtların ortalaması 4,00 olarak belirlenmiştir. Dolayısıyla hemşireler, yöneticilerine götürdükleri problemlerin düzeltilmesi veya varsa bir sorunlarına -ister iş yeri ile ilgili ya da diğer kişiselkarşı bir ilgisizlik kanısına sahiptirler. Bu sebeple bu yoğun ilgisizlik durumundan kaynaklanan sebeplerle örgütsel sessizliğin oluşması daha muhtemel bir hal almaktadır.

Örgüt içerisinde bulunan ast-üst ilişkileri ve dolayısıyla hiyerarşik yapı, çalışanlar üzerinde etki oluşturmaktadır. Bu hususta katılımcılara yöneltilen "Hiyerarşik yapının katılı̆̆ nedeniyle hemşireler sorunları dile getirmekten kaçınırlar." sorusuna katılımcıların \%69'sı olumlu yanıt verirken, \%18'i kararsız olduklarını ifade etmiştir. Ayrıca soruya verilen yanıtların ortalaması 3,90 olarak belirlenmiştir. Aslında insanoğlu gerçekte hiyerarşik yapılardan ve bu yapının getirdiği otorite ve baskıdan çoğunlukla hoşlanmazlar. Bunun yanı sıra çoğu zaman katı hiyerarşik yapıların da demokratik katılımı gerçekleştirmediklerinde baskıcı ve gayri insani bir nitelik kazandığını da söylemek mümkündür. Dolayısıyla katı hiyerarşik yapı nitelikleri nedeniyle hemşirelerde örgütsel sessizliğin görülme seviyesinin yüksek olmasını açıkladığını söyleyebiliriz.

Herhangi bir problem ile ilgili düşüncelerin dile getirilmesi örgütün gelişimi ve değişimi açısından değerli olsa da bazı kişiler karşıt düşüncelerden rahatsızlık duymaktadır. Bu bağlamda katılımcılara yöneltilen "Hemşireler sorun bildirenlerin hoş karşılanmayacağı düşüncesi ile susmayı tercih ederler." sorusuna katılımciların \%65,7'si olumlu yanıt verirken, \%14,7'si kararsız olduklarını belirtmiştir. Öte yandan soruya verilen yanitların ortalaması 3,62 olarak belirlenmiştir. Dolayısıyla hemşireler, çalışma arkadaşları veya yöneticilerin eylem ve uygulamalarıyla gerçekleştirdikleri -kurum ve hizmet alanlar açısında zararlı olabilecek durumları- yanlışlıkları kolaylıkla ifade etmedikleri sonucuna varılmaktadır. Hemşireler kınayıcı bakış ve görüşlerle karşılaşma ihtimalinden kaynaklı olarak örgütsel sessizlik durumuna büründüklerini söyleyebiliriz.

Örgütsel sessizlik durumunun ortaya çıkmasının sebeplerinden birisi de statü değişikliği yaşama korkusudur. $\mathrm{Bu}$ konuda katılımc1lara yöneltilen "Hemşireler sorun bildirdiğinde görev yeri değişme korkusu nedeni ile sorunlarl dile getirmezler." sorusuna \%72,8'i olumlu yanıt verirken, \%8,8'i kararsız olduklarını ifade etmiştir. Ayrıca soruya verilen yanitların ortalaması 3,80 olarak belirlenmiştir. Dolayısıyla görev yeri değişikliği ihtimali ile örgütsel sessizlik durumu görülmesinin vasat düzeyde olduğu söylenebilir.

İşgörenlerin tecrübeleri sonucunda önerilerde bulunmaları şüphesiz örgütün gelişimine katkıda bulunacaktır. Söz konusu katkı ise iş süreçlerinde olumlu sonuçlarıyla kurum ve hizmet alanların lehine olacak şekilde yansıyacaktır. $\mathrm{Bu}$ hususta katılımc1lara yöneltilen "Hemşireler yeni fikir ve önerileri iş yükünü artırabilir düşüncesinden dolayı susarlar. " sorusuna \%49,1'i olumlu yanıt verirken, \%22,9'si kararsız olduklarını belirtmiştir. Öte yandan soruya verilen yanıtların ortalaması 3,31 olarak belirlenmiştir. Dolayısıyla iş yükünün artma ihtimali nedeniyle örgütsel sessizliğin görülme durumunun vasat düzeyde olduğu söylenebilir. Bunun yanı sıra zaman zaman birçok kamu kurumunda fikir beyan eden, biraz iş bilen işgörenler bu durumu bir avantaj olarak görüp gösterme yoluna gitmezler. Çünkü çok sayıda niteliksiz ve dürüst bir iş erdemine sahip olmayanların işlerini de görmek zorunda kalabileceklerini birçok yerde ve zamanda müşahede etmişlerdir.

Kamu kurumlarında demokratik ve doğal olan tüm toplum kesimlerine mensup bireylerin buralarda görev yapmasıdır. Ancak farklılıklara tahammül etmeyen yönetimlerde karşıt görüşlüler yönetim tarafından tehdit unsuru olarak görülebilirler. Aynı şekilde farklı düşünce veya uygulama biçimlerine sahip olan fikirlerini beyan etmeyi kendileri açısından bir risk olarak gördüklerinden örgütsel sessizliğine bürünebilirler. $\mathrm{Bu}$ bağlamda katılımc1lara yöneltilen "Hemşireler kurumdaki geleceklerine dair kayglart nedeniyle kendilerine ait yeni fikirleri söylemezler." sorusuna katılımcıların \%62,8'i olumlu yanıt verirken, \%21,6'sı kararsız olduklarını ifade etmiştir. Bununla birlikte verilen yanıtların ortalaması 3,65 olarak belirlenmiştir. Dolayısıyla "gelecek korkusu" sebebiyle örgütsel sessizliğin meydana gelmesinin vasat düzeyde olduğu belirtilebilir.

Örgüt içerisinde yer alan mevcut durum kapsamında her işgörenin aynı zaman içerisinde yer aldığı kurum ve kuruluşlarda düşüncelerin iletimi kurum, hizmet alan ve işgören açısından sağlıklı bir işleyiş tarzıdır. Tarafların tamamının bilgi sahibi olmadığı konuda herkesin düşüncelerini dile getirmesini istemek yanlış sürece ve sonuca zemin hazırlayabilmektedir. Bu konuda katılımcılara yöneltilen "Hemşireler çalışma arkadaşlarının katılmadığı, işle ilgili konular hakkındaki fikirlerini ifade etmezler." sorusuna katılımciların \%50,6's1 olumlu yanıt verirken, \%22,5'si kararsız olduklarını belirtmiştir. Ayrıca soruya verilen yanıtların ortalaması 3,35 olarak belirlenmiştir. Dolayısıyla neredeyse hemşirelerin yarısı örgüt kültürünün ve ikliminin kaynaklanan sebeplerle örgütsel sessizlik içine girdikleri sonucu çıkarılabilir.

İşgörenler nezdinde yer alan çeşitli korku faktörlerinden biri de bilgi ve tecrübedir. Aslında bilginin bir güç olduğu ve insanı korkulardan azade kıldığını da biliyoruz. Bilgi ne kadar güçse bilgisizlikte bireyde korkulara sebep olması çok insani bir durumdur. Ancak meslek elemanlarının yeterince kendi alanlarındaki akademik ve uygulamalı becerileri edinememeleri şüphesiz çalışanların davranışlarını şekillendirmektedir. $\mathrm{Bu}$ hususta katılımc1lara yöneltilen "Hemşirelerin bilgisizlik ve deneyimsizlik korkusu duyguların ifade etmelerine engel olur." sorusuna katılımcıların \%50'si olumlu yanit verirken, \%16,7'si kararsız olduklarını ifade etmiştir. Öte yandan soruya verilen yanıtların ortalaması 3,15 olarak belirlenmiştir. Dolayısıyla bilgi ve deneyimler nedeniyle örgütsel sessizlik durumunun ortaya çıkmasının vasat düzeyde olduğu belirtilebilir.

Deneyimleri, bilgileri ve düşünceleri dile getirmenin zorluğunun yanı sıra zor zaman ve durumlar içerisinde konuşmak durumu daha çıkmaz bir hal almaktadır. Bu bağlamda katılımcılara yöneltilen "Hemşireler güç durumda konuşmaktan çok susmayı tercih ederler." sorusuna \%61,1'i olumlu yanıt verirken, \%19,3'ü kararsız olduklarını belirtmiştir. Ayrıca soruya verilen yanıtların ortalaması 3,46 olarak belirlenmiştir. Dolayısıyla güç durumlarda 
konuşamama nedeniyle örgütsel sessizliğin görülme durumunun vasat düzeyde olduğu öngörülmektedir.

Sorumluluğun üstlenildiği kademe de örgütsel sessizlik bakımından önem arz etmektedir. Bu konuda katılımcılara yöneltilen "Hemşireler alt kademede olduklarından dolayı bazl durumlarda susmayl tercih ederler." sorusuna katılımciların \%54'ü olumlu yanıt verirken, \%21,9'u kararsız olduklarını ifade etmiştir. Bununla birlikte soruya verilen yanıtların ortalaması 3,42 olarak belirlenmiştir. Dolayısıyla yer alınan kademe nedeniyle örgütsel sessizliğin görülme durumunun vasat düzeyde olduğu söylenebilir.

Örgütlerin çeşitli kademelerinde yer alan işgörenler açık bir şekilde düşüncelerini dile getirmeleri durumunda kurum içerisinde damgalanacakları veya ötekileştirilebilecekleri kanısına sahip olabilmektedirler. Bu hususta katılımcılara yöneltilen "Hemşireler duygu ve düşüncelerini açıkladıkları zaman güvende olmadlklarını hissederler." sorusuna katılımcıların \%63,4'ü olumlu yanıt verirken, \%19,6's1 kararsız olduklarını belirtmiştir. Öte yandan soruya verilen yanıtların ortalaması 3,58 olarak belirlenmiştir. Yine bu bağlamda katılımcılara yöneltilen "Hemşireler dışlanacakları endişesi ile sorunları dile getirmezler." sorusuna \%55,6's1 olumlu yanıt verirken, \%21,2'si kararsız olduklarını ifade etmiştir. Ayrıca soruya verilen yanıtların ortalaması 3,37 olarak belirlenmiştir. Dolayısıyla çalışanların dışlanma kapsamında yer alan faktörlerden kaynaklanan sebeplerle örgütsel sessizlik içerisinde yer alma durumlarının vasat düzeyde oldukları belirtilebilir.

İnsan, günlük yaşamında kabul, onay ve övgüye ihtiyacı olan bir varlıktır. Çünkü insanoğlu toplumsal yapılarda var olan sosyal ilişkiler çerçevesinde kendisini değerlendirmektir. İnsanın kendilik değeri ve benlik saygı da bu sosyal ilişki ağlarından etkilenmektedir. İşgörenler için aynı bölüm içerisinde yer alınan çalışma arkadaşları yanı sıra yöneticilerinin kendileri hakkındaki görüşleri önem arz eden bir husustur. $\mathrm{Bu}$ bağlamda olumsuz düşüncelere zemin hazırlamamak ve mevcut olumsuz fikirleri olumluya dönüştürebilme adına gayret sarf etmektedir. Bu konuda katılımcılara yöneltilen "Hemşireler sorun çıkarıcı ve şikâyetçi birisi olarak görünmek istemediklerinden olaylar ve durumlar karşısında sessiz kalmayı tercih ederler." sorusuna katılımciların \%61,1'i olumlu yanıt verirken, \%20,6'sı kararsız olduklarını belirtmiştir. Bununla birlikte soruya verilen yanitların ortalaması 3,51 olarak belirlenmiştir. Yine bu hususta katılımcılara yöneltilen "Iliş̧kilere zarar verme korkusundan dolayı hemşireler susarlar." sorusuna katılımcıların \%57,2'si olumlu yanıt verirken, \%23,5'si kararsız olduklarını ifade etmiştir. Ayrıca soruya verilen yanıtların ortalaması 3,46 olarak belirlenmiştir. Dolayısıyla başkalarının fikirlerini önemseme nedeniyle örgütsel sessizlik içerisinde bulunma durumunun vasat düzeyde olduğu söylenebilir.

\subsection{Güvenirlik Analizi}

Örgütsel Sessizlik Ölçeği:, Çakıcı (2008) tarafından geliştirilen "Örgütsel Sessizlik Nedenleri” anketi ve Kahveci ve Demirtaş (2013) tarafından geliştirilen "Örgütsel Sessizlik Ölçeği”nden yararlanarak yeni bir ölçek geliştirilmiştir. Ölç̧eğin gelişim süreci şu aşamalar altında gerçekleştirilmiştir;
- Araştırma konusu hakkında literatür taraması yapılmıştır.

- Literatür taraması sonucunda kullanilabilecek ölçekler belirlenmiştir.

- Daha sonra madde havuzu oluşturulmuştur.

- Madde havuzundan seçim yoluyla ölçekte kullanılabilecek ifadeler seçilmiştir.

- Uzman görüşü alınarak ölçek maddeleri araştırma amaçları doğrultusunda şekillendirilmiştir.

- Akabinde pilot uygulama yapılmıştır.

- Pilot uygulama önderliğinde elde edilen veriler geçerlilik ve güvenilirlik analizlerine tâbi tutulmuştur.

- $\quad \mathrm{KMO}$ değeri, açıklanan varyans katsayısı ile alpha değerleri incelenmiştir.

- Söz konusu değerlerin yeterlilik durumu literatür ile desteklenmiștir.

- Elde edilen sonuçlardan hareketle ölçeğin kullanılabilir olduğu kanaatine varılmıştır.

Ölçek 5'li likert tipi olup; "hiç katılmıyorum" (1) ile "tamamen katılıyorum" (5) kategorileri arasındadır. Söz konusu ölçeğe ilişkin güvenirlik analizi Tablo 5'te yer almaktadır.

Tablo 5. Güvenirlik Analizi

\begin{tabular}{ccc}
$\begin{array}{c}\text { Cronbach's } \\
\text { Alpha }\end{array}$ & $\begin{array}{c}\text { Cronbach's Alpha Based on } \\
\text { Standardized Items }\end{array}$ & $\begin{array}{c}\text { N of } \\
\text { Items }\end{array}$ \\
\hline, 924 &, 924 & 22 \\
\hline
\end{tabular}

\subsection{T Testi ve Anova Analizi}

Belirleyici analizlerden sonra katılımcıların örgütsel sessizlik nedenlerine dair düşüncelerini demografik değişkenlere göre karşılaştırmak amacıyla Bağımsız Örneklem T Testi ve Anova analizi yapılmıştır. Analizlerin örgütsel sessizlik ortalamalarının demografik özelliklere göre karşılaştırılması Tablo 6'da yer almakta olup aşağıda sunulmuştur.

Tablo 6. Örgütsel Sessizlik Ortalamalarının Demografik Özelliklere Göre Karşılaştırılması

\begin{tabular}{|c|c|c|c|c|}
\hline Değişken & Özellik & $\begin{array}{c}\mathbf{F} \\
(\mathrm{N}=306) \\
\end{array}$ & Ortalama & $\mathbf{P}$ \\
\hline \multirow{2}{*}{ Cinsiyet } & Kadın & 172 & 3,73 & \multirow{2}{*}{, 257} \\
\hline & Erkek & 134 & 3,64 & \\
\hline \multirow{3}{*}{ Yaş } & $18-25$ & 58 & 3,60 & \multirow{3}{*}{, 568} \\
\hline & $26-35$ & 202 & 3,71 & \\
\hline & $36-45$ & 46 & 3,68 & \\
\hline \multirow{4}{*}{$\begin{array}{l}\text { Eğitim } \\
\text { Durumu }\end{array}$} & İlköğretim & 2 & 3,68 & \multirow{4}{*}{,938 } \\
\hline & Lise & 28 & 3,72 & \\
\hline & Önlisans & 43 & 3,61 & \\
\hline & Lisans & 219 & 3,70 & \\
\hline
\end{tabular}




\begin{tabular}{cccc}
\hline & Lisansüstü & 14 & 3,62 \\
\hline \multirow{3}{*}{$\begin{array}{c}\text { Çalışma } \\
\text { Y1lı }\end{array}$} & $0-5$ & 130 & 3,71 \\
\cline { 2 - 4 } & $6-10$ & 126 & 3,65 \\
\cline { 2 - 4 } & $11-20$ & 41 & 3,70 \\
\cline { 2 - 4 } & $21+$ & 9 & 3,81 \\
\hline \multirow{3}{*}{ Yörev } & Acil Birim & 32 & 3,84 \\
\cline { 2 - 4 } & $\begin{array}{c}\text { Cerrahi } \\
\text { Birimler }\end{array}$ & 90 & 3,79 \\
\cline { 2 - 4 } & $\begin{array}{c}\text { Dahili } \\
\text { Birimler }\end{array}$ & 60 & 3,64 \\
\cline { 2 - 4 } & $\begin{array}{c}\text { Yoğun } \\
\text { Bakım }\end{array}$ & 80 & 3,53 \\
\cline { 2 - 4 } & Diğer & 44 & 3,72 \\
\hline
\end{tabular}

Tablo 6'da katılımcıların örgütsel sessizlik hakkındaki bilgi seviyeleri demografik değişkenler açısından incelenmiştir.

Cinsiyet değişkeni açısından; kadınların erkeklere göre örgütsel sessizlik durumlarının daha yüksek olduğu tespit edilmiştir ( $\mathrm{K}=3,73 \mathrm{E}=3,64)$. Ancak belirlenen bu farkın istatistiksel açıdan anlamlı olmadığı sonucuna ulaşılmıştır $(\mathrm{p}=0,257>0,05)$.

Yaş değişkeni açısından; gruplar arasında örgütsel sessizlik düzeylerinin farklılaştığı belirlenmiştir. Ancak söz konusu farklılık, istatistiksel açıdan anlamlı değildir $(\mathrm{p}=0,568>0,05)$. Ayrıca gruplar arasındaki en yüksek örgütsel sessizlik seviyesine sahip olanların " $26-35$ " yaş grubu olduğu tespit edilmiştir $(18-25=3,60 ; 26-35=3,71 ; 36$ $45=3,68)$.

Eğitim durumu değişkeni bakımından; grupların arasında örgütsel sessizlik seviyeleri bakımından farklılık olduğu sonucuna ulaşılmıştır. Söz konusu farklılık istatistiksel açıdan anlamlı değildir $(p=0,938>0,05)$. Bununla birlikte gruplar arasında en yüksek örgütsel sessizlik seviyesine sahip olanların lise grubunda yer alan kişiler olduğu sonucuna ulaşı1lmıştır (İlköğretim $=3,68$; Lise $=3,72$; Ön Lisans $=3,61$; Lisans $=3,70$; Lisansüstü=3,62).

Çalışma yılı değişkeni açısından; gruplar arasında bir farklılık tespit edilmiş olup, söz konusu farklılı̆̆ın istatistiksel açıdan anlamlı olmadığı sonucuna ulaşılmıştır $(\mathrm{p}=0,848>0,05)$. Ayrıca gruplar arasında en yüksek örgütsel sessizlik seviyesine sahip kişilerin $21+$ grubunda yer alan kişiler olduğu belirlenmiştir $(0-5=3,71 ; 6-10=3,65 ; 11$ $20=3,70 ; 21+=3,81$ ).

Görev yeri değişkeni bakımından; gruplar arasında farklılık olduğu belirlenmiş olup, en yüksek örgütsel sessizlik seviyesine sahip olanların acil birim grubunda yer alan bireyler olduğu sonucuna ulaşılmıştır (Acil Birim=3,84; Cerrahi Birimler $=3,79$; Dahili Birimler $=3,64$; Yoğun Bakım=3,53; Diğer=3,72). Ancak belirlenen farklılığın istatistiksel açıdan anlamlı olmadığı sonucuna ulaşılmıştır $(\mathrm{p}=0,103>0,05)$.

Ölçek ifadelerinin demografik özelliklere göre karşılaştırılmasının ardından faktör ortalamaları da demografik özelliklere göre karşılaştırılmıştır. Bu bağlamda yönetici faktörü Tablo 7'de, sessizliğin kaynağı faktörü Tablo 8'de, iş ile ilgili korku faktörü Tablo 9'da, ilişkileri zedeleme korkusu faktörü Tablo 10'da demografik özelliklere göre karşılaştırılmıştır.

Tablo 7. Yönetici Faktörünün Demografik Değişkenlere Göre Farklılaşması

\begin{tabular}{|c|c|c|c|c|c|}
\hline Değişken & Özellik & $\begin{array}{c}\mathbf{F} \\
(\mathrm{N}=306)\end{array}$ & $\begin{array}{c}\text { Ortala } \\
\text { ma }\end{array}$ & $\mathbf{P}$ & \\
\hline \multirow{2}{*}{ Cinsiyet } & Kadın & 172 & 4,04 & \multirow{2}{*}{,018 } & \multirow{2}{*}{$r^{2}=0,41$} \\
\hline & Erkek & 134 & 3,84 & & \\
\hline \multirow{3}{*}{ Yaş } & $18-25$ & 58 & 4,08 & \multirow{3}{*}{, 061} & \\
\hline & $26-35$ & 202 & 3,96 & & \\
\hline & $36-45$ & 46 & 3,74 & & \\
\hline \multirow{5}{*}{$\begin{array}{l}\text { Eğitim } \\
\text { Durumu }\end{array}$} & $\begin{array}{c}\text { İlköğreti } \\
\text { m }\end{array}$ & 2 & 3,37 & \multirow{5}{*}{,089 } & \\
\hline & Lise & 28 & 3,84 & & \\
\hline & Önlisans & 43 & 3,73 & & \\
\hline & Lisans & 219 & 4,02 & & \\
\hline & $\begin{array}{c}\text { Lisansüs } \\
\text { tü }\end{array}$ & 14 & 3,83 & & \\
\hline \multirow{4}{*}{$\begin{array}{c}\text { Çalışma } \\
\text { Y1lı }\end{array}$} & $0-5$ & 130 & 4,08 & \multirow{4}{*}{$\begin{array}{c}, 048 \\
\text { a-b }\end{array}$} & \\
\hline & $6-10^{\mathrm{a}}$ & 126 & 3,89 & & \\
\hline & $11-20^{\mathrm{b}}$ & 41 & 3,75 & & \\
\hline & $21+$ & 9 & 3,90 & & \\
\hline \multirow{5}{*}{$\begin{array}{l}\text { Görev } \\
\text { Yeri }\end{array}$} & $\begin{array}{c}\text { Acil } \\
\text { Birim }\end{array}$ & 32 & 4,05 & \multirow{5}{*}{,945 } & \\
\hline & $\begin{array}{c}\text { Cerrahi } \\
\text { Birimler }\end{array}$ & 90 & 3,96 & & \\
\hline & $\begin{array}{c}\text { Dahili } \\
\text { Birimler }\end{array}$ & 60 & 3,95 & & \\
\hline & $\begin{array}{l}\text { Yoğun } \\
\text { Bakım }\end{array}$ & 80 & 3,91 & & \\
\hline & Diğer & 44 & 3,95 & & \\
\hline
\end{tabular}

Tablo 7'de katılımcıların demografik değişkenleri yönetici faktörü açısından incelenmiştir.

Cinsiyet değişkeni açısından; kadınların yönetici faktörü kapsamında erkeklere göre örgütsel sessizlik durumlarının daha yüksek olduğu sonucuna ulaşıılmıştır $(K=4,04 \mathrm{E}=3,84)$. Bununla birlikte belirlenen bu fark istatistiksel açıdan anlamlıdır $(\mathrm{p}=0,018<0,05)$. Yönetici faktöründen oluşan örgütsel sessizlik değişiminin 0,41 'ini cinsiyet değiş̧eni tarafından açıklanmaktadır.

Yaş değişkeni açısından yönetici faktörü incelendiğinde gruplar arasında örgütsel sessizlik düzeylerinin farklılaştığı tespit edilmiştir. Ancak söz konusu farklılık, istatistiksel açıdan anlamlı değildir $(\mathrm{p}=0,061>0,05)$. Ayrıca gruplar 
arasındaki en yüksek örgütsel sessizlik seviyesine sahip olanların "18-25" yaş grubu olduğu tespit edilmiştir (18$25=4,08 ; 26-35=3,96 ; 36-45=3,74)$.

Yönetici faktörü bakımından eğitim durumu değişkeni incelendiğinde, gruplar arasında farklılık olduğu belirlenmiştir. Fakat söz konusu farklılık istatistiksel açıdan anlamlı değildir $(\mathrm{p}=0,089>0,05)$. Bununla birlikte gruplar arasında en yüksek örgütsel sessizlik seviyesine sahip olanların lisans grubunda yer alan kişiler olduğu sonucuna ulaşılmıştır (İlköğretim= 3,37; Lise=3,84; Ön Lisans =3,73; Lisans=4,02; Lisansüstü=3,83).

Çalışma yılı değişkeni yönetici faktörü açısından değerlendirildiğinde, gruplar arasında bir farklılık tespit edilmiştir. Tespit edilen farklılık istatistiksel açıdan anlamlıdır $(p=0,048<0,05)$. Belirlenen farklılığın hangi gruplar arasında olduğunu belirlemek amaciyla Tukey testi yapılmıştır. Tukey testi sonuçlarına göre söz konusu farklılığın '6-10' ile '11-20' grupları arasında olduğu tespit edilmiştir. Ayrıca gruplar arasında en yüksek örgütsel sessizlik seviyesine sahip kişilerin 0-5 grubunda yer alan kişiler olduğu belirlenmiştir $(0-5=4,08 ; 6-10=3,89 ; 11$ $20=3,75 ; 21+=3,90)$. Yönetici faktöründen oluşan örgütsel sessizlik değişiminin 0,57 'sini çalışma yılı değişkeni tarafından açıklanmaktadır.

Görev yeri değişkeni yönetici faktörü bakımından incelendiğinde, gruplar arasında farklılık olduğu sonucuna ulaşılmıştır. Ayrıca en yüksek örgütsel sessizlik seviyesine sahip olanların acil birim grubunda yer alan bireyler olduğu tespit edilmiştir (Acil Birim=4,05; Cerrahi Birimler=3,96; Dahili Birimler=3,95; Yoğun Bakım=3,91; Diğer=3,95). Ancak belirlenen farklılı̆̆ın istatistiksel açıdan anlamlı olmadığ 1 sonucuna ulaşılmıştır $(p=0,945>0,05)$.

Tablo 8. Sessizliğin Kaynağı Faktörünün Demografik Değişkenlere Göre Farklılaşması

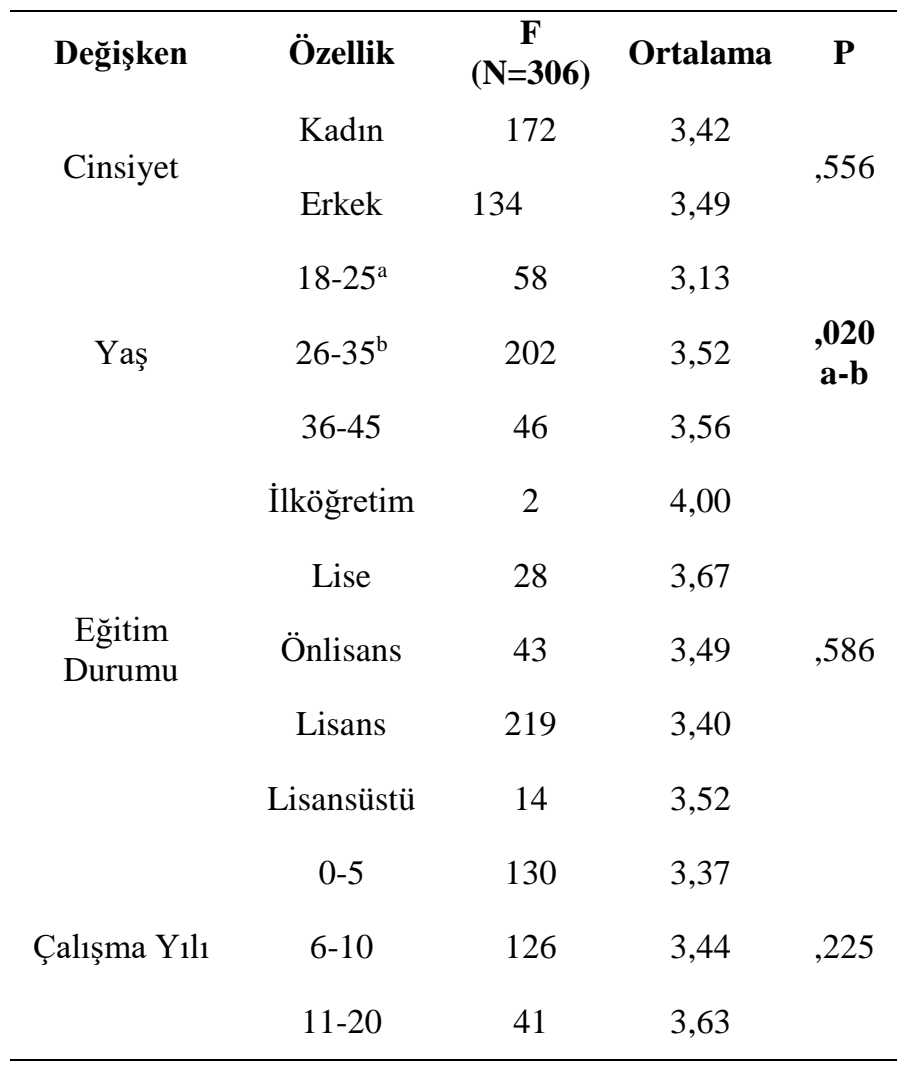

\begin{tabular}{ccccc}
\hline & $21+$ & 9 & 3,91 & \\
& Acil Birim & 32 & 3,65 & \\
Cerrahi & 90 & 3,64 & \\
Görev Yeri & $\begin{array}{c}\text { Birimler } \\
\text { Dahili } \\
\text { Birimler } \\
\text { Yoğun } \\
\text { Bakım }\end{array}$ & 60 & 3,37 & $\mathbf{, 0 0 9}$ \\
& a-b \\
& Diğer & 44 & 3,16 & \\
\hline
\end{tabular}

Tablo 8'de katılımcıların demografik değişkenleri sessizliğin kaynağı faktörü açısından incelenmiştir.

Cinsiyet değişkeni sessizliğin kaynağı faktörü açısından değerlendirildiğinde, erkeklerin kadınlara göre örgütsel sessizlik durumlarının daha yüksek olduğu sonucuna ulaşılmıştır $(\mathrm{K}=3,42 \mathrm{E}=3,49)$. Ancak belirlenen bu fark istatistiksel açıdan anlamlı değildir $(\mathrm{p}=0,556>0,05)$.

Sessizliğin kaynağı faktörü açısından yaş değişkeni incelendiğinde, gruplar arasında örgütsel sessizlik düzeylerinin farklılaştığı belirlenmiştir. Ayrıca söz konusu farklılık, istatistiksel açıdan anlamlıdır $(p=0,020<0,05)$. Belirlenen farklılığın hangi gruplar arasında olduğunu belirlemek amacıyla Tukey testi yapılmıştır. Tukey testi sonuçlarına göre söz konusu farklılığın '18-25' ile '26-35' grupları arasında olduğu tespit edilmiştir. Yanı sıra gruplar arasındaki en yüksek örgütsel sessizlik seviyesine sahip olanların " $36-45$ " yaş grubu olduğu tespit edilmiştir (18$25=3,13 ; 26-35=3,52 ; 36-45=3,56$ ).

Eğitim durumu değişkeni sessizliğin kaynağı faktörü bakımından değerlendirildiğinde, gruplar arasındaki örgütsel sessizlik seviyelerinin farklılaşmaktadır. Fakat söz konusu farklılık istatistiksel açıdan anlamlı değildir $(\mathrm{p}=0,586>0,05)$. Bununla birlikte gruplar arasında en yüksek örgütsel sessizlik seviyesine sahip olanların ilköğretim grubunda yer alan kişiler olduğu sonucuna ulaşılmıştır (İlköğretim=4,00; Lise $=3,67 ; \quad$ Ön Lisans $=3,49 ; \quad$ Lisans $=3,40$; Lisansüstü=3,52).

Çalışma yılı değişkeni sessizliğin kaynağı faktörü açısından değerlendirildiğinde, gruplar arasında bir farklılık tespit edilmiştir. Fakat belirlenen farklılık istatistiksel açıdan anlamlı değildir $(\mathrm{p}=0,225>0,05)$. Ayrıca gruplar arasında en yüksek örgütsel sessizlik seviyesine sahip olanların 21+ grubunda yer alan kişiler olduğu belirlenmiştir $(0-5=3,37 ; 6$ $10=3,44 ; 11-20=3,63 ; 21+=3,91)$.

Görev yeri değişkeni sessizliğin kaynağı faktörü bakımından; gruplar arasında farklılık göstermektedir. Ayrıca söz konusu faktör kapsamında en yüksek örgütsel sessizlik seviyesine sahip olanların acil birim grubunda yer alan kişiler olduğu tespit edilmiştir (Acil Birim=3,65; Cerrahi Birimler=3,64; Dahili Birimler $=3,37$; Yoğun Bakım=3,16; Diğer=3,56). Ayrıca belirlenen farklılı̆̆ın istatistiksel açıdan anlamlı olduğu sonucuna ulaşılmıştır $(p=0,009<0,05)$. Belirlenen farklılığın hangi gruplar arasında olduğunu belirlemek amacıyla Tukey testi yapılmıştır. Tukey testi sonuçlarına göre söz konusu farklılığın 'Dahili Birimler' ile 'Yoğun Birimler' grupları arasında olduğu tespit edilmiştir. 
Tablo 9. İş İle İlgili Korku Faktörünün Demografik Değişkenlere Göre Farklılaşması

\begin{tabular}{|c|c|c|c|c|}
\hline Değişken & Özellik & $\begin{array}{c}F \\
(\mathrm{~N}=306)\end{array}$ & Ortalama & $\mathbf{P}$ \\
\hline \multirow{2}{*}{ Cinsiyet } & Kadın & 172 & 3,36 & \multirow{2}{*}{,975 } \\
\hline & Erkek & 134 & 3,37 & \\
\hline \multirow{3}{*}{ Yaş } & $18-25$ & 58 & 3,21 & \multirow{3}{*}{,308 } \\
\hline & $26-35$ & 202 & 3,37 & \\
\hline & $36-45$ & 46 & 3,51 & \\
\hline \multirow{5}{*}{$\begin{array}{l}\text { Eğitim } \\
\text { Durumu }\end{array}$} & İlköğretim & 2 & 3,87 & \multirow{5}{*}{,654 } \\
\hline & Lise & 28 & 3,58 & \\
\hline & Önlisans & 43 & 3,40 & \\
\hline & Lisans & 219 & 3,34 & \\
\hline & Lisansüstü & 14 & 3,19 & \\
\hline \multirow{4}{*}{$\begin{array}{l}\text { Çalışma } \\
\text { Yyl1 }\end{array}$} & $0-5$ & 130 & 3,33 & \multirow{4}{*}{,388 } \\
\hline & $6-10$ & 126 & 3,31 & \\
\hline & $11-20$ & 41 & 3,61 & \\
\hline & $21+$ & 9 & 3,41 & \\
\hline \multirow{5}{*}{$\begin{array}{l}\text { Görev } \\
\text { Yeri }\end{array}$} & Acil Birim & 32 & 3,60 & \multirow{5}{*}{$\begin{array}{l}\text {,017 } \\
\text { a-b }\end{array}$} \\
\hline & $\begin{array}{c}\text { Cerrahi } \\
\text { Birimler }\end{array}$ & 90 & 3,55 & \\
\hline & $\begin{array}{c}\text { Dahili } \\
\text { Birimler }\end{array}$ & 60 & 3,36 & \\
\hline & $\begin{array}{l}\text { Yoğun } \\
\text { Bakım }^{\text {a }}\end{array}$ & 80 & 3,08 & \\
\hline & Diğer ${ }^{b}$ & 44 & 3,33 & \\
\hline
\end{tabular}

Tablo 9'da katılımcıların demografik değişkenleri iş ile ilgili korku faktörü açısından incelenmiştir.

Cinsiyet değişkeni açısından; erkeklerin kadınlara göre örgütsel sessizlik durumlarının iş ile ilgili korku faktörü kapsamında daha yüksek olduğu sonucuna ulaşılmıştır $(\mathrm{K}=3,36 ; \mathrm{E}=3,37)$. Ancak belirlenen bu fark istatistiksel açıdan anlamlı değildir $(\mathrm{p}=0,975>0,05)$.

Yaş değişkeni açısından; gruplar arasında örgütsel sessizlik düzeyleri iş ile ilgili korku faktörü çerçevesinde farklılaşmaktadır. Ancak söz konusu farklılık, istatistiksel açıdan anlamlı değildir $(p=0,308>0,05)$. Ayrıca gruplar arasındaki en yüksek örgütsel sessizlik seviyesine sahip olanların "36-45" yaş grubu olduğu sonucuna ulaşılmıștır $(18-25=3,21 ; 26-35=3,37 ; 36-45=3,51)$.

İş ile ilgili korku faktörü bakımından eğitim durumu değişkeni bakımından incelendiğinde, gruplar arasında örgütsel sessizlik seviyelerinin farklılık gösterdiği tespit edilmiştir. Fakat söz konusu farklılık istatistiksel açıdan anlamlı değildir $(\mathrm{p}=0,654>0,05)$. Bununla birlikte gruplar arasında en yüksek örgütsel sessizlik seviyesine sahip olanların ilköğretim grubunda yer alan kişiler olduğu sonucuna ulaşılmıştır (İlköğretim= 3,87; Lise=3,58; Ön Lisans =3,40; Lisans=3,34; Lisansüstü=3,19).

Çalışma yılı değişkeni iş ile ilgili korku faktörü açısından değerlendirildiğinde, gruplar arasında bir farklılık tespit edilmiştir. Fakat belirlenen farklılık istatistiksel açıdan anlamlı değildir $(p=0,388>0,05)$. Ayrıca gruplar arasında en yüksek örgütsel sessizlik seviyesine sahip olanların 11-20 grubunda yer alan kişiler olduğu belirlenmiştir $(0-5=3,33 ; 6$ $10=3,31 ; 11-20=3,61 ; 21+=3,41)$.

Görev yeri değişkeni iș ile ilgili korku faktörü bakımından incelendiğinde, gruplar arasında farklılık olduğu belirlenmiş olup, en yüksek örgütsel sessizlik seviyesine sahip olanların acil birim grubunda yer alan kişiler olduğu tespit edilmiştir (Acil Birim =3,60; Cerrahi Birimler=3,55; Dahili Birimler=3,36; Yoğun Bakım=3,08; Diğer=3,33). Belirlenen farklılığın hangi gruplar arasında olduğunu belirlemek amacıyla Tukey testi yapılmıştır. Tukey testi sonuçlarına göre söz konusu farklılığın 'Yoğun Bakım' ile 'Diğer' grupları arasında olduğu tespit edilmiştir. Ayrıca belirlenen farklılığın istatistiksel açıdan anlamlı olduğu sonucuna ulaşıllmıştır $(\mathrm{p}=0,017<0,05)$.

Tablo 10. İlişkileri Zedeleme Korkusu Faktörünün Demografik Değişkenlere Göre Farklılaşması

\begin{tabular}{|c|c|c|c|c|}
\hline Değişsen & Özellik & $\begin{array}{c}F \\
(N=306)\end{array}$ & Ortalama & $\mathbf{P}$ \\
\hline \multirow{2}{*}{ Cinsiyet } & Kadın & 172 & 3,83 & \multirow{2}{*}{, 113} \\
\hline & Erkek & 134 & 3,67 & \\
\hline \multirow{3}{*}{ Yaş } & $18-25$ & 58 & 3,62 & \multirow{3}{*}{,328 } \\
\hline & $26-35$ & 202 & 3,78 & \\
\hline & $36-45$ & 46 & 3,84 & \\
\hline \multirow{5}{*}{$\begin{array}{l}\text { Eğitim } \\
\text { Durumu }\end{array}$} & İlköğretim & 2 & 3,70 & \multirow{5}{*}{,928 } \\
\hline & Lise & 28 & 3,67 & \\
\hline & Önlisans & 43 & 3,69 & \\
\hline & Lisans & 219 & 3,79 & \\
\hline & Lisansüstü & 14 & 3,72 & \\
\hline \multirow{4}{*}{$\begin{array}{c}\text { Çalışma } \\
\text { Y1lı }\end{array}$} & $0-5$ & 130 & 3,77 & \multirow{4}{*}{,950 } \\
\hline & $6-10$ & 126 & 3,74 & \\
\hline & $11-20$ & 41 & 3,76 & \\
\hline & $21+$ & 9 & 3,91 & \\
\hline \multirow{3}{*}{$\begin{array}{c}\text { Görev } \\
\text { Yeri }\end{array}$} & Acil Birim & 32 & 3,88 & \multirow{3}{*}{,320 } \\
\hline & $\begin{array}{c}\text { Cerrahi } \\
\text { Birimler }\end{array}$ & 90 & 3,86 & \\
\hline & $\begin{array}{c}\text { Dahili } \\
\text { Birimler }\end{array}$ & 60 & 3,63 & \\
\hline
\end{tabular}




\begin{tabular}{ccc}
\hline $\begin{array}{c}\text { Yoğun } \\
\text { Bakım }\end{array}$ & 80 & 3,66 \\
\hline Diğer & 44 & 3,83 \\
\hline
\end{tabular}

Tablo 10'da katılımcıların demografik değişkenleri ilişkileri zedeleme korkusu faktörü açısından incelenmiştir.

Cinsiyet değişkeni açısından; kadınların erkeklere göre örgütsel sessizlik durumları ilişkileri zedeleme korkusu faktörü kapsamında daha yüksektir ( $\mathrm{K}=3,83$; $\mathrm{E}=3,67)$. Ancak belirlenen bu fark istatistiksel açıdan anlamlı değildir $(\mathrm{p}=0,113>0,05)$.

Yaş değişkeni açısından; gruplar arasında örgütsel sessizlik düzeyleri ilişkileri zedeleme korkusu faktörü açısından farklılaşmaktadır. Ancak söz konusu farklılık, istatistiksel açıdan anlamlı değildir $(\mathrm{p}=0,328>0,05)$. Ayrıca gruplar arasındaki en yüksek örgütsel sessizlik seviyesine sahip olanların " $36-45$ " yaş grubu olduğu sonucuna ulaşılmıştır $(18-25=3,62 ; 26-35=3,78 ; 36-45=3,84)$.

Eğitim durumu değişkeni bakımından; gruplar arasında örgütsel sessizlik seviyeleri ilişkileri zedeleme korkusu faktörü açısından farklılık göstermektedir. Fakat söz konusu farklılık istatistiksel açıdan anlamlı değildir $(p=0,928>0,05)$. Bununla birlikte gruplar arasında en yüksek örgütsel sessizlik seviyesine sahip olanların lisans grubunda yer alan kişiler olduğu tespit edilmiştir (İlköğretim=3,70; Lise =3,67; Ön Lisans =3,69; Lisans=3,79; Lisansüstü=3,72).

Çalışma yılı değişkeni ilişkileri zedeleme korkusu faktörü açısından değerlendirildiğinde, gruplar arasında bir farklılık tespit edilmiştir. Fakat belirlenen farklılık istatistiksel açıdan anlamlı değildir ( $\mathrm{p}=0,950>0,05)$. Ayrıca gruplar arasında en yüksek örgütsel sessizlik seviyesine sahip olanların 21+ grubunda yer alan kişiler olduğu belirlenmiştir $(0-5=3,77 ; 6$ $10=3,74 ; 11-20=3,76 ; 21+=3,91)$.

Görev yeri değişkeni ilişkileri zedeleme korkusu faktörü bakımından değerlendirildiğinde, gruplar arasında farklılık olduğu belirlenmiştir. Yanı sıra en yüksek örgütsel sessizlik seviyesine sahip olanların acil birim grubunda yer alan kişiler olduğu tespit edilmiştir (Acil Birim=3,88; Cerrahi Birimler=3,86; Dahili Birimler=3,63; Yoğun Bakım=3,66; Diğer=3,83). Ayrıca belirlenen farklılığın istatistiksel açıdan anlamlı olmadığ 1 sonucuna ulaşılmıştır $(p=0,320>0,05)$.

\section{Sonuç ve Öneriler}

Hemşirelerin örgütsel sessizlik nedenlerini konu edinen bu çalışma, örgütsel sessizlik konusunu çeşitli açıdan değerlendirmiştir. Hemşirelerin vardiyalı çalışma sistemi, nöbet izinleri ile hemşirelere ulaşım durumu araştırmanın sınırlılığı olarak kabul edilmektedir.

Bu çalışma bir Eğitim ve Araştırma Hastanesi’nde görevli 306 hemşirenin katılımıyla oluşturulan veri setinin çeşitli metotlarla analiz edilmesiyle gerçekleştirilmiştir. Yapılan analiz sonuçlarına göre katılımcıların genel anlamda örgütsel sessizlik nedenlerinin yüksek-vasat düzey arasında olduğu tespit edilmiştir.
Bağımsız Örneklem $\mathrm{T}$ Testi ve Anova analiziyle araştırmanın hipotezleri test edilmiştir. Elde edilen verilere göre hipotezler reddedilmiştir.

Ölçekte yer alan ifadeler içerisinde en fazla katılımı \%82,3 ile "Hastane yöneticilerinin "en iyi ben bilirim" tavr hemşireler üzerinde olumsuz bir etki yaratır." sorusu almıştır. Ayrıca söz konusu ifadenin düzeyi ölçekte yer alan ifadeler arasında 4,21 ortalama ile en yüksek düzeyde yer almıştır. Bu bağlamda hastane yöneticilerinin tutum ve davranışlarından kaynaklanan sebeplerle örgütsel sessizliğin görülme durumunun yüksek düzeyde olduğu kolaylıkla söylenebilir. Öte yandan ölçekte yer alan ifadeler içerisinde en az katılımı \%49,1 ile "Hemşireler yeni fikir ve öneriler iş yükünü artırabilir düşüncesinden dolayı susarlar." sorusu almıştır. Dolayısıyla personelin iş yükünün artması düşüncesini ifade etmesi ve örgütsel sessizlik arasında doğrudan bir ilişkinin çok yüksek bir düzeye sahip olmadığı katılımcıların görüşleri ile desteklenmiştir.

Araştırma faktörlerinin demografik özelliklere göre karşılaştırılmasında anlamlı sonuçlar elde edilmiştir.

Yönetici faktörü açısından cinsiyet değişkeni ile çalışma yılı değişkeni anlamlı bir farklılık göstermektedir. Buna göre yönetici sebebiyle kadınların örgütsel sessizlik durumunun erkeklere kıyasla daha fazla olduğu söylenebilir. Bununla birlikte 0-5 yıl arasında çalışma yılına sahip olanların yöneticileri tarafından daha fazla örgütsel sessizlik durumuna maruz bırakıldıkları öngörülmektedir. Kadınlar toplumsal rolleri sebebiyle çalışma hayatlarında çeşitli problemler ile karşı karşıya kalmaktadır. Söz konusu problemler nedeniyle erkeklere kıyasla daha fazla sessizlik içerisinde bulundukları düşünülmektedir. Aynı şekilde örgüt kapsamında çalışma yılı fazla olan kişiler kurumları ile ilgili daha fazla bilgiye sahiptir. Bu kapsamda çıraklık dönemi olarak da değerlendirilebilecek 0-5 yıl arasında çalışanlar örgüt hakkında daha az bilgiye sahiptir. Dolayısıyla yöneticilerine karşı daha fazla sessizlik durumu içerisinde bulundukları öngörülmektedir.

Sessizliğin kaynağı faktörü açısından yaş değişkeni ile görev yeri değişkeni anlamlı bir farklılık göstermektedir. Bu bağlamda 36-45 yaş arasında yer alan kişilerin daha fazla sessizliğin kaynağı sebepleri ile sessizlik içerisinde bulunduğu tespit edilmiştir. Ayrıca acil birimde çalışanların örgütsel sessizlik durumlarının sessizliğin kaynağı nedenleri ile daha fazla sessizlik içerisinde olduğu sonucuna ulaşılmıştır.

İş ile ilgili korku faktörü açısından görev yeri değişkeni anlamlı bir farklılık göstermektedir. Buna göre acil birimde yer alan personelin iş ile ilgili korku faktörü nedeniyle daha fazla örgütsel sessizlik içerisinde olduğu öngörülmektedir. Acil birimde görevli olan personel diğer birimlere kıyasla daha hayati durumlar ile karşı karşıya kalmaktadır. Hayati durumların yanı sıra ilgili personelin daha hızlı bir şekilde sağlık hizmeti sunmaları gerekmektedir. Dolayısıyla herhangi bir aksaklık ile yanlış tutum acil birimler kapsamında geri dönüşü olmayan sonuçlara yol açabilmektedir. $\mathrm{Bu}$ sebeple iş ile ilgili korku faktörü kapsamında acil birim personelinin daha fazla sessizlik içerisinde yer aldığ 1 düşünülmektedir. 
Bütün bu sonuçlardan yola çıkarak, örgütsel sessizliğin sağlık kurumlarında azaltılabilmesi için öneriler şu şekildedir;

- Bilinç ve farkındalık kazandırıcı faaliyetler bağlamında da işgörende baskı, şiddet, örselenme, mobbing, özsaygı ve kendilik değerini azaltma gündemleştirilmelidir.

- Eğitimler, seminerler ve konferans gibi toplantılar aracılığıyla ast-üst ilişkilerinin pozitif olması sağlanmalıdır.

- Personelini daha iyi tanıma, anlama, empati kurma, olumlu kabul, özerklik, motivasyon ve yenilik konusunda destekleme gibi konularda yöneticilere yönelik eğitimler de önem arz etmektedir.

- Eğitimlere ek olarak çalışanlar ile düzenlenecek olan sosyo-kültürel etkinliklerin örgütsel sessizliğin azaltımında olumlu etki oluşturacağ düşünülmektedir.

\section{Kaynakça}

Alparslan, A. M. (2010). Örgütsel Sessizlik ve İşgören Sessizlik Davranışlarl Arasındaki Etkileşim: Mehmet Akif Ersoy Üniversitesi Öğretim Elemanları Üzerinde Bir Araştırma. Yüksek Lisans Tezi. Isparta: Süleyman Demirel Üniversitesi.

Balc1, A. (2003). Örgütsel sosyalleşme kuram, strateji ve taktikler. Ankara: Pegem A Yayınları.

Bayın, G., Yeşilaydın, G., \& Esatoğlu, A. E. (2015). Hemşirelerde Örgütsel Sessizlik Nedenlerinin Belirlenmesi. Işletme Araştırmaları Dergisi, 7(1), 248-266.

Bildik, B. (2009). Liderlik Tarzlarl, Örgütsel Sessizlik ve Örgütsel Băglllık İlişkisi. Yüksek Lisans Tezi. Kocaeli: Gebze Yüksek Teknoloji Enstitüsü.

Can, A., \& Alparslan A. M. (2012). Hemşireler Neden Sessiz Kalırlar?: Bir Iç̧erik Analizi Çalışması. 6. Sağlık ve Hastane İdaresi Kongresi Bildiriler Kitab1, 261-266.

Çakıc1, A. (2007). Örgütlerde Sessizlik: Sessizliğin Teorik Temelleri ve Dinamikleri. Çukurova Üniversitesi Sosyal Bilimler Enstitüsü Dergisi, 16(1),145-162.

Çakıcı, A. (2008). Örgütlerde Sessiz Kalınan Konular, Sessizliğin Nedenleri ve Algılanan Sonuçları Üzerine Bir Araştırma. Çukurova Üniversitesi Sosyal Bilimler Enstitüsü Dergisi, 17(1), 117-134.

Çakıcı, A. (2010). Örgütlerde işgören sessizliği. Ankara: Detay Yayıncilik.

Deniz, N., Noyan, A., \& Ertosun, Ö. G. (2013). The Relationship between Employee Silence and Organizational Commitment in a Private Healthcare Company. Procedia-Social and Behavioral Sciences, 99, 691-700.

Durak, İ. (2012). Korku kültürü ve örgütsel sessizlik. Bursa: Ekin Yayınevi.

Erigüç, G., Özer, Ö., Sonğur, C., \& Turaç, İ. S. (2014). Bir Devlet Hastanesinde Hemşirelerde Örgütsel Sessizlik
Üzerine Bir Araştırma. Çankırı Karatekin Üniversitesi İktisadi ve İdari Bilimler Fakültesi Dergisi, 4 (2), 61-84.

Freire, P. (2018). Ezilenlerin pedagojisi. Dilek Hattatoğlu (Çev.) İstanbul: Ayrıntı Yayınları.

Gül, H., \& Özcan, N. (2011). Mobbing ve Örgütsel Sessizlik Arasındaki İlişkiler: Karaman İl Özel İdaresinde Görgül Bir Çalışma. Kahramanmaraş Sütçü İmam Üniversitesi İktisadi ve İdari Bilimler Fakültesi Dergisi, 1(2), 107-134.

Gürbüz, S., \& Şahin, F. (2016). Sosyal bilimlerde araştırma yöntemleri. Ankara: Seçkin Yayıncılık.

Kahveci, G. (2010). İlköğretim Okullarında Örgütsel Sessizlik İle Örgütsel Bă̆lılık Arasındaki İlişkiler. Yüksek Lisans Tezi. Elazığ: Fırat Üniversitesi.

Kahveci, G., \& Demirtaş, Z. (2013). Öğretmenler İçin Örgütsel Sessizlik Ölçeği Geliştirme Çalışması. Elektronik Sosyal Bilimler Dergisi, 12(43), 167-182.

Karacaoğlu, K., \& Cingöz, A. (2008). Örgütsel sessizlik. İçinde: Özdevecioğlu, M., \& Karadal, H. (Ed.) Örgütsel davranışta seçme konular - organizasyonların karanlı yönleri ve verimlilik azaltıcı davranışlar. (s. 155-167). Ankara: İlke Yayınevi.

Kılınç, E., \& Ulusoy, H. (2014). Investigation Of Organizational Citizenship Behavior, Organizational Silence And Employee Performance At Physicians And Nurses, And The Relationship Among Them. Business Management Dynamics, 3(11), 25-34.

Milliken, F. J., Morrison, E. W., \& Hewlin, P. F. (2003). An Exploratory Study Of Employee Silence: Issues That Employees Don't Communicate Upward And Why. Journal of Management Studies, 40(6), 1453-1476.

Tabachnick, B. G., \& Fidell, L. S. (2007). Experimental designs using ANOVA. Thomson/Brooks/Cole.

Ritzer, G., \& Stepnisky, J. (2014). Sosyoloji kuramlart. Himmet Hülür (Çev.). Ankara: De Ki Basım Yayım.

Özgen, I., \& Sürgevil, O. (2009). Örgütsel sessizlik olgusu ve turizm işletmeleri açısından değerlendirilmesi. İçinde: Z. Sabuncuoğlu (Ed.) Turizm işletmelerinde örgütsel davranış. (s. 303-328). Bursa: MKM Yayınları.

Pinder, C. C., \& Harlos, K. P. (2001). Employee Silence: Quiescence And Acquiescence As Responses To Perceived Injustice. Research In Personnel And Human Resources Management, 20, 331-369.

Premeaux, S.F., \& Bedeian, A.G. (2003). Breaking The Silence: The Moderating Effects Of Self-Monitoring In Predicting Speaking Up In The Workplace. Journal of Management Studies, 40(6), 1537-1562.

Sandel, M. J. (2014). Adalet: yapılması gereken doğru şey nedir?, Ankara: BigBang Yayınları.

Sargut, S. A. (1994). Kültürler arası farklılaşma ve yönetim. Ankara: Versa Yayıncılık.

Silah, M. (2005). Sosyal psikoloji davranış bilimi. Ankara: Seçkin Yayıncılık. 
Şimşek, E. (2011). Örgütsel İletiş̧im ve Kişilik Özelliklerinin Yaşam Doyumuna Etkileri. Doktora Tezi. Eskişehir: Anadolu Üniversitesi.

Tayfun, A., \& Çatır, O. (2013). Örgütsel Sessizlik ve Çalışanların Performansları Arasındaki İlişki Üzerine Bir Araştırma. İşletme Araşstırmaları Dergisi, 5(3), 114-134.

TÜIKK Sağlık Personeli Sayısı, 2018.

Tikici, M., Derin, N., \& Kalkın, G. (2011). Örgütsel Sessizliğin Duygusal Tükenmişliğe Etkisi. 7. Kobi'ler ve Verimlilik Kongresi Bildiri Kitab1, TC İstanbul Kültür Üniversitesi Yayınları Yayın No: 155.
Uçar, Z. (2016). İşgören Sessizliği: Teorik Yaklaşımlar Temelinde Betimsel Bir Analiz. BEU Akademik İzdüşüm, 1(1), 67-86.

Van Dyne, L., Ang, S., \& Botero, I. C. (2003). Conceptualizing Employee Silence And Employee Voice As Multidimensional Constructs. Journal of Management Studies, 40(6), 1359-1372.

Yalçın, B. Y., \& Baykal, Ü. (2012). Özel Hastanelerde Görevli Hemşirelerin Sessiz Kaldığı Konular ve Sessiz Kalma Nedenleriyle İlişkili Faktörler. Hemşirelikte Eğitim ve Araştırma Dergisi, 9(2), 42-50. 


\section{Extended Abstract}

Aim: This study aims to examine the problem of organizational silence among nurses, who are one of the employee groups performing important tasks in health institutions. All processes through which health services are provided - healthcare professionals and their senior managers, healthcare professionals and patients receiving healthcare services - are carried out through patterned connections of social relations. These patterned forms of social relations reveal their existence in daily life by feeding from the values and socio-cultural codes existing in the society. These values found in the institutional or individual attitudes, actions, and behaviors of people are shaped by being influenced by socio-cultural codes. Considering the aforementioned situation, it is necessary to know the communication styles of healthcare personnel both with their coworkers and the administrators of the institutions they work in. Discussing the concept of organizational silence, the research also focuses on the subject of organizational silence in health institutions in the context of nurses - as a form of intermediate employee.

Method: The research population consists of nurses employed in a training and research hospital. 957 nurses work in the health institution where the research was conducted. The sample size of the research was calculated using the relevant formula at a $95 \%$ confidence level. As a result of this calculation, the minimum size through which the sample should represent the population was determined to be 278 people. The research sample consists of data obtained from 306 nurses working in the related institution. The simple random sampling method was used in the research. Parametric tests were used due to the normal distribution of the data. In addition to descriptive analyzes, the data obtained were analyzed through unpaired t-test and ANOVA tests.

Conclusion: As a result of the evaluation of the research data, it was determined that hospital managers play a significant role in the reasons for organizational silence of nurses, as an employee form. The gender variable and the working year variable display a significant difference in terms of the manager factor. Accordingly, it was revealed that women's level of organizational silence is higher compared to men's due to the manager factor. It can be expressed that the fact that women are more well-behaved (quiet, calm, accepting their duties without questioning), obedient, and more tolerant to problems in the institutions they work in is caused by gender-based values. In addition to this, as a result of the analysis of the research data, it was revealed that employees with working years between 0-5 years are exposed to more organizational silence by their managers. It can be expressed that this result indicates the existence of young employees who do not want to lose their jobs in a country with high unemployment. There is a significant difference between the age variable and the place of duty variable in terms of the cause of the silence factor. In this regard, it was determined that the organizational silence level of people between the ages of 36-45 is higher due to the cause of the silence factor. The place of duty variable also displays a significant difference in terms of the work-related fear factor. Accordingly, it was concluded that the organizational silence level of the personnel in the emergency unit is higher due to the work-related fear factor. 


\section{EK-1: Etik Kurul Formu:}

\section{ETIK KURUL KARARI}

\begin{tabular}{|c|c|c|c|}
\hline $\begin{array}{c}\text { TOPLANTI } \\
\text { TARIHI }\end{array}$ & $\begin{array}{c}\text { TOPLANTI } \\
\text { SAYISI }\end{array}$ & $\begin{array}{c}\text { KARAR } \\
\text { NO }\end{array}$ & CALIȘMACININ ADI SOYADI \\
\hline 10.01 .2019 & 16 & 6 & Doç.Dr.Rifat BILGIN \\
\hline
\end{tabular}

\section{KARAR}

"Hemşirelerde Örgütsel Sessizliğin Nedenleri: Bir Eḡitim ve Araştırma Hastanesi Örneği". konulu çalışma etik kurulumuzda görüşulmùs olup; çalıșmanın etik kurallara uygun olduğuna oybirligiyle karar verilmiştir.

\begin{tabular}{|c|c|c|c|}
\hline \multicolumn{2}{|c|}{$\begin{array}{l}\text { Prof. Dr. Mehmet Nuri GÖMI.EKSIZ } \\
\text { (Başkan) }\end{array}$} & \multirow[b]{2}{*}{$\begin{array}{l}\text { Doc. Dr. Rufat BILGiN } \\
\text { (Oye) }\end{array}$} & \multirow[b]{2}{*}{ Bulunamad } \\
\hline $\begin{array}{c}\text { Doç. Dr. Sebahattin } \\
\text { DEVECIOGLU } \\
\text { (Uye) }\end{array}$ & Bulunamadı & & \\
\hline $\begin{array}{c}\text { Doç. Dr, Süleyman ILHAN } \\
\text { (Üye) }\end{array}$ & Bulunamadı & $\begin{array}{c}\text { Doç.Dr. Haki PESSMAN } \\
(\overline{\mathrm{C} y \mathrm{e})}\end{array}$ & Imza \\
\hline $\begin{array}{l}\text { Doç. Dr. Irfan EMRE } \\
\text { (Uye) }\end{array}$ & $\operatorname{Imza}$ & $\begin{array}{c}\text { Dr, Oggr. Oyesi Serkan BlC̨ER } \\
(\text { Oye })\end{array}$ & Bulunamadı \\
\hline $\begin{array}{l}\text { Doç. Dr. Taner YILDIRIM } \\
\text { (Ûye) }\end{array}$ & Imza & $\begin{array}{c}\text { Dr.Ör. Oyesi Ayşe Ülkü KAN } \\
\text { (Û̀ye) }\end{array}$ & Imza \\
\hline $\begin{array}{l}\text { Doç.Dr. Erkan Turan DEMIREL } \\
\text { (Oye) }\end{array}$ & Imza & $\begin{array}{c}\text { Dr.Ögr. Oyesi Yunus Emre } \\
\text { KARAKAYA } \\
\text { (Öye) }\end{array}$ & Imza \\
\hline
\end{tabular}

